
GÜNAH VE ŞEFAAT MESELELERİ (ZEMAHSŞERÎ, ȚABERSî, RĀẐ̂ ÖRNEĞINDE)

\title{
Mehmet Bağıș*
}

\section{$\ddot{O} z$}

Sahabe devrinden sonra farklı İslam merkezlerinde ilim medreseleri teşekkül etmiştir. Sonraki süreçte fikri birer ekol haline gelen bu medreselerin farklı anlayışlara sahip olması, beraberinde yeni fikhî ve kelâmî mezhepler ile tasavvuf akımlarının doğmasına sebep olmuştur. Şiâ, Ehl-i Sünnet ve Mu'tezile bu minvalde teşekkül etmiş kelâmî mezheplerdendir. Söz konusu bu mezheplerin farklı bakış açılarına sahip olması, onların Kur'ân yorumunu da etkilemiş ve bu bakış açısı doğrultusunda tefsirler kaleme almışlardır. Mu'tezile mezhebine mensup olan Zemahsşerî'nin el-Keşşâf, Şî'â'ya mensup olan Țabersî’nin Mecme'u'l-Beyān ve Ehl-i Sünnet'e mensup olan Râzî'nin Mefätīhu'l-Gayb adlı eserleri bu şekilde değerlendirilen tefsirlerdendir.

Mezhebi tefsir olarak da addedilen yukarıdaki üç eserde müellifler, tefsire dair yaklaşımlarında genellikle kelâmî mezheplerine bağlı kalmış ve Kur'ân ayetlerini o minvalde yorumlamışlardır. Bu çalışmada, kelâm ilmi alanında tartışma konusu olan iman-amel ilişkisi bağlamında büyük günah ve şefaat meseleleri, söz konusu üç eserde karşılaştırmalı olarak ele alınmıştır. Neticede müfessirlerin bu konularla ilgili ayetleri kendi mezhep nosyonları çerçevesinde yorumladıkları görülmüştür.

Anahtar Kelimeler: Tefsir, Mu'tezile, Şiâ, Ehl-i Sünnet, Büyük Günah, Şefaat.

\section{INTERCESSION AND GREAT SIN ISSUES IN THE CONTEXT OF FAITH- ACTION IN SECTARIAN EXEGESES (EXAMPLE OF ZEMAḨŞERÎ, TABERSî, AND RĀẐ̂)}

\begin{abstract} Gayb are among the tafsirs written in this way.

Article Types / Makale Türü: Research Article / Araştırma Makalesi

Received / Makale Geliş Tarihi: 03.06.2020, Accepted / Kabul Tarihi: 22.08.2020

DOI: https://doi.org/10.26791/sarkiat.801949

*Şırnak Üniversitesi İlahiyat Fakültesi Tefsir A.B.D mbagiss@hotmail.com,

ORCID ID: : https://orcid.org/0000-0002-5605-8813
\end{abstract}

After the time of the Companions, scientific madrasahs were formed in different Islamic centers. These madrasahs, whose ideas have become schools, have different understandings. These schools led to the emergence of new Islamic and theological sects and mysticism. Şiâ is one of the theological sects of Ahl as-Sunnah and Mu'tezile. The fact that these sects have different points of view also affected their interpretation of the Quran. Zemahşserî's al-Keşşāf, TTabersî's Mecme'u'l-Beyān and Râzî's Mefătīḥu'l-

In the above three works, which are also regarded as sectarian exegesis, the authors generally adhered to the theological sects in their approach to exegesis. They interpreted the verses of the Quran in this manner. In this study, major sin and intercession issues are dealt with comparatively in these works. As a result, it was seen that the 
commentators interpret the verses related to these issues within the framework of their sectarian notions.

Keywords: Commentary, Sectarian Exegeses, Great Sin, Intercession

\section{GíRiş}

Hicri birinci asırda fitne olaylar olarak da isimlendirilen siyasi olaylar neticesinde farklı anlayışa sahip fırkalar teşekkül etmiştir. Çeşitli inanç konularında farklı düşünen her bir firka görüşünün doğruluğunu ispatlamak üzere Kur'ân ayetlerine müracaat etmiştir. Fırkalar, benimsedikleri yolun doğruluğunu ispatlama adına kendi mezheplerine uygun düşen ayetleri almış, aykırı olanı ise tevil etme yoluna gitmişlerdir. Kur'ân'da bağlamından koparıldığında kader, cebr ve teşbih gibi bazı anlayışlara işaret edebilecek ayetlerin varlığ 1 bu durumu daha da kolaylaştırmıştır.

İslam'ın ilk devirlerinde çoğunlukla rivayete dayanan, yüzeysel ve sınırlı konularda olan ayetlerin tefsiri, problemlerin çoğalması ve düşüncelerin gelişmesi neticesinde farklı boyutlara ulaşmıştır. Özellikle gayri İslami unsurların Müslümanlara karşı düşünsel anlamda üstün gelme çabası, tabiri caizse Müslümanların karşı atağa geçmesine sebebiyet vermiş ve onların sahip oldukları mantık ve felsefe metotlarını kullanmalarına yol açmıştır. Bunun neticesinde müfessirler, kelamcıların da etkisiyle Kur'ân tefsirinde yeni ufuklar açmışlardır. ${ }^{1}$

İtikadi firkalar oluşumlarını tamamlayıp sistemleştikten sonra mezhep müntesipleri müfessirler de sem iyâta dair ayetleri tefsir etmede, benimsedikleri mezhebin görüşleri tesirinde kalmışlardır. İman-amel meselesi, büyük günah işleyen kimsenin dünya ve ahiretteki durumu, şefaat meselesi, cennet cehennemin varlığ1 ve kabir azabının mahiyeti gibi mezhebi tefsirlerde tartışılan başlıca sem iyât konuları, müfessirlerce farklı şekillerde tefsir edilmiştir.

İtikadi mezheplerin tefsirdeki yaklaşımlarını ortaya koyma sadedinde yaptığımız bu çalışmada Ehl-i Sünnet, Şî‘â ve Mu'tezile mezhepleri esas alınacaktır. Bu mezheplere müntesip alimlerin sem iyât konularına dair ayetleri tefsir etmedeki yaklaşımı, her bir mezhepten sadece birer örneklem oluşturmak suretiyle ortaya konulmaya çalışılacaktır. Dolayısıyla söz konusu örneklemin, mezhebin yaklaşımını ortaya koyabilecek nitelikte bir eser olmasına dikkat edilmiştir. Bu bağlamda hicri altıncı asırda yazılmış tefsirlerden; Mu'tezilī olan Zemahşşerî'nin el-Keşşāf'1, Şî́â mezhebine mensup Ṭabersî'nin Mecme'u'l-Beyān'ı, ve Ehl-i Sünnet'e mensup olan Râzî'nin Mefātīḥu'l$\dot{G} a y b$ '1 örnek alınmıştır.

Yukarıda sözü geçen tefsirlerdeki sem iyât konularının tamamının incelenmesi daha geniş çapta çalışmalara ihtiyaç duyduğundan çalışmamızı sadece iki temel problemle sınırlandıracağız. Bunlardan biri, iman-amel ilişkisi bağlamında büyük günah diğeri ise aynı bağlamda şefaat meselesidir. Dolayısıyla diğer sem 'îyât konuları çalışmamızın kapsamı dişında tutulmuştur. Bununla birlikte, söz konusu problemleri ele almadan önce esas aldığımız müfessir ve ilgili tefsirlerini kısaca tanıtmayı uygun bulmaktayız.

\footnotetext{
${ }^{1}$ Bk. İsmail Cerrahoğlu, Tefsir Tarihi (Ankara: Fecr Yay., 2014), 233.
} 


\section{ZEMAHSŞERÎ, TABERSî, RÂZÎ VE TEFSİRLERI 1.2. Zemahşerî ve el-Keşşāf Tefsiri}

Ebu'l-Kāsım Mạ̣mūd b. Ömer ez-Zemahsşerî, hicri 467 yılında Ḩavārezm kasabasına bağlı Zemahşer'de doğmuştur. ${ }^{2}$ Mütedeyyin ve fakir bir aileye mensup olan Zemahşserî, ilim tahsili için pek çok ilim merkezine yolculuk yapmıştır. Arap dil ve edebiyatını Abū Mażr ${ }^{3}$ ve Ebû Manșūr'dan almıştır. ${ }^{4}$ Ebû Ṭāhir Sāmān b. 'Abdilmelik b. el-Hüseyn esSāmānî de ondan hadis aktarmıştır. ${ }^{5}$ Hocası Maḥmūd b. Cerīr ed-Żabbī el-İ́sfehānī'den (öl. 507/1113) çokça etkilenen Zemahşerî i'tizālī fikirleri ondan almış ve onun sayesinde ilmi ve siyasi çevrelerde tanınmıştır. ${ }^{6}$ Kendi döneminin imamı ve Havārezm'in övünç kaynağı olan Zemahşerî, özellikle Arap dili ve edebiyatı konusunda otorite kabul edilmiştir. ${ }^{7}$ Zemahşserî, hicri 538/1144 yılı 'Arefe gecesinde Havārezm'de vefat etmiştir. ${ }^{8}$

Zehebî'nin kendisini salih bir kişi, müfessir ve i’tizālī fikirlerin propagandasını yapan biri, şeklinde tanıttığı Zemahşerî; 9 Tefsir, Hadis, Kelam, Arap Dili ve Edebiyatı gibi pek çok alanda eser te'lif etmiştir. el-Keşşâff 'an Hakāiki't-Tenzīl, el-Fäik fi'l-G̈arībi'lHadīs, Rabī 'u'l-Ebrār, Esmāu'l-Evdiye ve'l-Cibāl, el-Müfred ve'l-Müellif fi' $n$-Naḥv ve el-Mufașsal fi' $n$-Naḥv ${ }^{10}$, onun başlıca eserlerinden sadece bir kaçıdır.

Zemahşerî, en meşhur eseri olan el-Keşşāf 'an Hakāiki Gavāmżi't-Tenzīl adlı tefsirini hicri 526-528 yıllarında Mekke'de yazmıştır. Eserinin mukaddimesinde Kur'ân'1 tefsir eden kişide bulunması gereken özelliklerden, bu işin önem ve zorluklarından söz eden müellif, kendisine gelen yoğun talep doğrultusunda Keşşăf'1 kaleme aldığını ifade etmiştir. ${ }^{11}$

Metot olarak sure başlarında, o sure ile ilgili bilgilere yer veren Zemahşşerî; akli, nakli ve lafzi delālet çerçevesinde ayetleri tefsir ederken; kıraat farklılıklarına ${ }^{12}$ sebebi nüzûle ${ }^{13}$ usūl kaidelerine ${ }^{14}$ surelerin faziletine ${ }^{15}$ fikhi ihtilaflara ${ }^{16}$, mesellere, şiire, Arap

\footnotetext{
2 'Abdurraḥmān b. Muḥammed b. 'Ubeydullāh el-Enșārī/ Kemāluddīn el-Enbārī, Nüzhetü'l-Elbā' fì

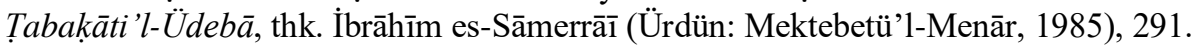

${ }^{3}$ Kemāluddīn el-Enbārī, Nüzhetü'l-Elbā', 290.

${ }^{4}$ Eserlerine dair ayrıntılı bilgi için ayrıca bk. Ebu'l-Fidā Zenūdudīn Ebu'l- 'Adl Kāāsım b. Kutluboğa, Tācu't-Terācim, thk. Muḥammed Ḩayr Ramażan Yūsuf (Dimeşk: Dāru'l-Kalem, 1992), 291, 292.

${ }^{5}$ Muḥammed b. 'Abdilg̀an̄̄ b. Ebī Bekr b. Şucā', İkmālü'l-İkmāl, thk. 'Abdulḳayyum (Mekke: Cāmia 'tu Ümmü'l-Kurā, 1989), 3/121, 493.

${ }^{6}$ Cerahoğlu, Tefsir Tarihi, 264-265.

7 Mustafa Öztürk, Mehmet Suat Mertoğlu, “Zemahsşerî”, Türkiye Diyanet Vakfi Íslam Ansiklopedisi (İstanbul: TDV Yay., 2013), 236.

${ }^{8}$ Ebu'l-'Abbās Aḥmed b. Hasan b. el-Ḩatīb, el-Vefayāt, thk. 'Ādil Nuveyhịid (Beyrūt: Dāru'l-Āfāḳi'lCedīde, 1983), 278; Kemāluddīn el-Enbārī, Nüzhetü'l-Elbā', 292.

9 Şemsuddīn Ebū 'Abdillāh Muḥammed b. Aḥmed b. Osmān ez-Zehebî, el-Muginnī fi 'ż-Żu 'a'fā, thk. Nureddīn 'Itr (B.y.: Y.y., ts), 2/647; Mīzānu'l-ì'tidāl, thk. 'Alī Muhammed el-Becāvī (Beryut: Dāru'lMa'rife, 1963), 4/78. İbn Hacer de Zemahşşî için buna benzer ifadelere yer vermiş ve Keşşāf' indan sakındırmıştır. Bk. Ebu'l-Fażl Aḥmed b 'Alī b. Muḥammed b. Aḥmed b. Hacer el- Askelān̄̄, Lisānu'lMìzān, thk. Dāiretu'l-Mu 'arrifi'n-Nizāmiyye Hindistan (Beyrut: Müessesetü’l-A 'lemi, 1971), 6/4.

${ }^{10}$ Kemāluddin el-Enbārī, Nüzhetü'l-Elbā', 290. Zemahşşê̂’nin basılmış ve yazma halinde bulunan diğer eserleri için ayrıca bk. Cerahoğlu, Tefsir Tarihi, 266; Enver Arpa, Zemahşerî̀nin Tefsirdeki Yeri (Ankara: Fecr Yay., 2012), 43.

11 Ebu'l-Kasım Maḥmūd b. 'Amr b. Aḥmed ez-Zemahş̧erî, el-Keşşāf 'an Haḳāiḳi Ġavāmżi't-Tenzīl (Beyrut: Dāru'l-Kütübi'l- 'İlmiyye, 1986), 1/3.

12 Zemahşserî, el-Keşşāaf, 1/11.

${ }^{13}$ Zemahş̧erî, el-Keşşāf, 1/206, 1/235, 1/253, 2/435, 3/481, 4/205.

${ }^{14}$ Zemahş̧erî, el-Keşşă $f, 1 / 58,1 / 237$.
} 
dili ve belağatının inceliklerine ${ }^{17}$ de yer vermiştir. Bazı ayetleri, ayetle tefsir eden müellif, ${ }^{18}$ hadis rivayetlerinden de sıkça istifade etmiştir. ${ }^{19}$

İlim ehlinin müstağni kalamayacağı bu alim ve tefsiriyle alakalı kitap, tez ve makale düzeyinde yüzlerce çalışma yapılmıştır. ${ }^{20}$

\section{2. Ṭabersî ve Mecme'u'l-Beyān Tefsiri}

Ebû 'Alī el-Fażl b. el-Ḥasen et-Ṭabersî, bazı rivayetlere göre Kāşān'da bazı rivayetlere göre de Isfahan'da doğmuştur. Künyesi Ebû 'Ali olup, meşhur nisbesi Ṭabersî' dir. İlim ehli bir ailede yetişen ${ }^{21}$ Ṭabersî, hicri 548/1153 y1lında Sebzvār'da vefat etmiştir. ${ }^{22}$

Țabersî'in tefsir fikıh ve kelam alanlarında kaleme aldığı bazı eserleri şunlardır: Mecme 'u'l-Beyān li 'Ulūmi'l-Kur'ân, Cevāmi 'u'l-Cāmī', Muhtașaru'l-Keşşāâ, Tãcü'lMevālìd, Nūru'l-Mübīnu'l-Fāik, Künūzu'n-Necāh. ${ }^{23}$

Genç yaşta tefsirini yazan Țabersî, Mecme 'u'l-Beyān li 'Ulümi'l-Kur'ân adlı bu tefsirinin mukaddimesinde de ifade ettiği gibi sure başlarında, ilgili surenin Mekkî veya Medenî olduğuna yönelik bilgiye, ayet sayısıyla alakalı ihtilaflara, surenin faziletine, kıraat farklılıklarına, i' rāb tahlillerine ve ayrıca ayetler arasındaki uyum ve insicama yer vermiştir. ${ }^{24}$ Müfessir, eserin hacmini daraltmak maksadıyla hadis ehlince meşhur hadislerin senedlerine yer vermemiştir. ${ }^{25}$ Farsça'ya tercüme edilen eserin üzerinde farklı ihtisar çalışmaları da mevcuttur. ${ }^{26}$

\subsection{Râzî ve Mefātīḥu'l-Ġayb Tefsiri}

Tam ismi Muhammed b. Ömer b. el-Ḥüseyn b. Ali el-Ḳureşī et-Teymī, el-Bekrī, etṬaberistānī olan müellifin künyesi Ebû 'Abdillāh ve Ebu'l-Fażl olup, hicri 543/1149 yılının Ramazan ayında doğmuştur. İlmi alandaki vükûfiyeti sebebiyle Fahruddīn erRâzî lakabıyla meşhur olmuştur. ${ }^{27}$ Şâfi 'î ve Eş'arî kaynaklarında "İmam" ünvanıyla anılan Râzî; tefsir, fikıh, kelam, felsefe, tıp, astronomi matematik gibi pek çok ilim alanında eser verdiği için ayrıca " allame” ünvanıyla da anılmıştır. ${ }^{28}$

\footnotetext{
${ }^{15}$ Zemahşşî̀, el-Keşşā $f, 4 / 394,4 / 430$.

${ }^{16}$ Zemahşşî, el-Keşşâff, 1/18, 180, 560; 2/615; 3/129; 4/488.

${ }^{17} \mathrm{Bk}$. Zemahşerî, el-Keşşāff, 1/3, 8, 13, 14 .

${ }^{18} \mathrm{Bk}$. Zemahş̧erî, el-Keşşāaff, 1/13.

${ }^{19}$ Örneğin bk. Zemahşserî, el-Keşşāf, 1/4, 18.

20 Bk.: Mehmet Kaya, "Keşşāf Tefsiri Hakkında Yapılmış Akademik Araştırmalar: Bir Literatür İncelemesi", AUID 6/10 (Haziran 2018), 402. Esra Gözeler, "Zemahşerî Araştırmaları: Bir Literatür İncelemesi", Kelam Araştırmaları Dergisi 14/1 (2016), 84-101.

21 Muhammed Seyyid Hüseyin ez-Zehebî, et-Tefsîr ve'l-Müfessirūn (Kahire: Mektebetü Vehbe, ts.), $2 / 74$.

22 Muștafā b. el-Hüuseyn el-Hüseyn̄̄ et-Tefrișī, Naḳdu'r-Ricāl, thk. Müessesetü Āli'l-Beyti li İhyāi'tTürāṣ (Kūum: Müessesetü Āli'l-Beyt li İhyyāi’t-Türāṣ, 1997), 4/19. Ayrıca bk. Nesrişah Saylan, “Ṭabersî’nin Kırraatlerin Hüccetinde Kullandığı Delillerin İncelenmesi”, Cumhuriyet Ilahiyat Dergisi 23/2 (Aralık 2019), 977-991, 981.

23 Cerahoğlu, Tefsir Tarihi, 367.

${ }^{24}$ Ebū Alī el-Fażl b. el-Hasen et-Ṭabersî, Mecme 'u'l-Beyān li Tefsîri'l-Kur'ān (Beyrut: Dāru'l- 'Ulūm, 2005), $1 / 8$.

25 Țabersî, Mecme 'u'l-Beyān, 1/6.

${ }^{26}$ Mustafa Öz, "Ṭabersî” Türkiye Diyanet Vakfi İslam Ansiklopedisi, (İstanbul: TDV Yay., 2010), $39 / 325$.

${ }^{27}$ Cemālüddīn Ebu'l-Hasan 'Alī b. Yūsuf el-Kıfțī, Ahbāru'l- 'Ulemā bi Ahyāri'l-Hukemā, thk. İbrāhīm Şemsuddīn (Beyrut: Dāru'l-Kütübi'l-'İlmiyye, 2005), 220.

${ }^{28}$ Yusuf Şevki Yavuz, "Râzî”, Türkiye Diyanet İslam Ansiklopedisi (İstanbul: TDV Yay., 1995), 12/89.
} 
Kendi döneminin en önemli siması ve Şâfi î mezhebinin müntesibi olan Râzî, pek çok öğrenci yetiştirmiş ve zamanında Ehl-i Sünnet'in en büyük savunucusu olmuştur. ${ }^{29}$ Râzî, h. 606/1210 yılının Ramazan Bayramı'nda Herat'ta vefat etmiştir. ${ }^{30}$

Rāzi'nin pek çok alanda yazdığı eserleri içerisinde Mefātīḥu'l-Ġayb adlı tefsiri ayrı bir yere sahiptir. Bu eserinde dirayet metodunu takip eden müellif, pek çok ilmi alana dair bilgiler aktarmıştır. ${ }^{31}$ Râzî, tefsirinde rivayetlere, ${ }^{32}$ kıraat farklılıklarına, sebeb-i nüzüle vb. pek çok hususa yer vermiştir. ${ }^{33}$

Ayetlerin tefsirinde itikadî mezheplerin görüşlerini tartışmanın yanı sıra fikhi mezheplerin yaklaşımlarına da yer veren Râzî, Kelām, Astronomi, Felsefe, Tıp gibi farklı alanlarla alakalı pek çok bilgi aktarmıştır. ${ }^{34}$ Sahih aklın sahih nakille çatışmayacağ 1 fikrine sahip olan Rāzi, tefsirinde akli unsura çokça yer vermiştir. ${ }^{35}$

Yazıldığ 1 dönemden itibaren pek çok tefsire kaynaklık eden bu tefsir, çağdaş dönemde de çok sayıda tez ve makaleye konu olmuştur. ${ }^{36}$

\section{IMAN-AMEL İLIŞKİSİ BAĞLAMINDA BÜYÜK GÜNAH VE ŞEFAAT MESELELERI}

İslam tarihinde siyasi ve toplumsal olaylar neticesinde, önce politik bir mesele olarak ortaya çıkan sonra da dini bir hal alan $^{37}$ ve en önemli kelâmî problemlerden kabul edilen büyük günah işleyen kimsenin durumu; sonraki dönemlerde de Mu'tezile, Şî́â ve Ehl-i Sünnet alimleri tarafindan tartışılmaya devam etmiştir. Büyük günah işleyenlerin durumuna nispeten daha geç bir dönemde tartışma konusu haline gelen ve bir önceki konuyla bağlantılı olan diğer bir konu da şefaatin kimler için vâkî olacağ hususudur. $^{38}$ $\mathrm{Bu}$ iki meseleye dair farklı yaklaşımlar, sonraki dönemlerde yazılan mezhebi tefsirlere de yansımıştır. Bunun sebebi, her iki konuyla alakalı ayetlerin farklı şekillerde yorumlanmasından kaynaklanabildiği gibi her mezhep mensubunun kendi görüşüne Kur'ân'dan delil getirme çabasından da kaynaklanabilmiştir.

Biz de çalışmamızın bu başlığında, mezhebi tefsirlerde iki problemin çözümüne yönelik öne sürülen yaklaşımların, itikadi mezheplerin görüşleriyle olan alakasını ve mezheplerin etkisinde kalıp kalmadıklarını incelemeye çalışacağız.

\footnotetext{
29 Ebū 'Abbās Şemsudīn Aḥmed b. Muḥammed b. İbrāhīm b. Ebī Bekr el-Bermekī el-İrbilī, Vefāyātu'l'Ayān ve Enbāu Ebnāi'z-Zemān, thk. İhsān 'Abbas (Beyrut: Dāru Ṣādir, 1994), 4/251.

30 Bermekī, Vefāyātu'l- 'Ayān, 4/252.

31 Cerahoğlu, Tefsir Tarihi, 606. Diğer eserlerine dair ayrıntılı bilgi için bk.: Kıfțī, Ehbāru'l-Ulemā, 221; Yavuz, "Râzî", 12/93-94.

32 Muḥammed b. Ömer b. el-Hüseyn b. 'Ali el-Kureşī et-Teymī Fahruddīn er-Râzî, Mefätīhu'l-Gayb/et-

Tefsîru'l-Kebīr (Beyrut: Dāru İhyāi't-Turāsi'l- 'Arabiyy, 1999), 1/22.

${ }^{33}$ Râzî'nin genel tefsir-tevil tarzı ile et-Tefsîru'l-Kebīr'in belli başıı özellikleri hakkında ayrıntılı bilgi için bk.: Râzî'nin tefsir anlayışına dair yapılan çalışmalar için bk. Mustafa Öztürk, "Tefsirde Farheddin er-Râzî”, İslām Düşüncesinin Dönüşüm Çağında Fahreddin er-Râzî, ed. Ömer Türker- Osman Demir (İstanbul: İSAM Yay., 2013), 286.

${ }^{34}$ Fahruddīn er-Râzî, Mefätīhu'l-Ġayb, 1/34, 67, 105, 10/178, 11/311, 23/312, 1/33, 22/20.

35 Cerahoğlu, Tefsir Tarihi, 609.

${ }^{36}$ Râzî'nin tefsir anlayışına dair yapılan çalışmalar için bk. Öztürk, “Tefsirde Farheddin er-Râzî”, 279

37 Mustafa Türkgülü, "Günah Kavramı ve İman Problemi Haline Getirilen Büyük Günah/Kebire Hakkındaki Kelāmī Tartışmalar”, Diyanet İlmi Dergi 36/4 (Ekim-Kasım-Aralık 2000), 68.

${ }^{38}$ Bk. Ethem Rûhi Fığlalı, Gümüz İslam Mezhepleri (İzmir: İzmir İlahiyat Vakfi Yay., 2008), 128.
} 


\subsection{Zemahşerî, Ṭabersî ve Râzî’nin Tefsirlerinde İman-Amel İlişkisi Bağlamında Büyük Günah}

İman, sözlükte "tasdik" manasına gelmektedir. Istılahī olarak ise iman kavramı hakkında farklı tanımlar yapılmıştır. Bu tanımlardan ilki, "sadece kalp ile tasdik etmek" şeklindedir. İkincisi "sadece dil ile ikrar etmek", üçüncüsü "kalp ile tasdikin yanında dil ile ikrar etmek" ve dördüncüsü de "kalp ile tasdik, dil ile ikrar ve diğer uzuvlarla amel etmek" şeklindedir. ${ }^{39}$

Kelâmî açıdan imân "esasları, amelle münasebeti, artıp eksilmesi ve müminin vasıfları" gibi açılardan ele alınmıştır. ${ }^{40}$

Ehl-i Sünnet'e göre iman; Hz. Peygamber'e, Allah (c.c) tarafından getirdiği şeylerde tereddütsüz bir şekilde inanmaktır. Diğer bir deyişle, Hz. Peygamber'in Allah'tan (c.c) alıp kesin olarak din adına tebliğ ettiği şeyleri tasdik etmeye, onlara inanmaya denir. Bu inanca sahip olan kişilere de mümin denilmektedir. ${ }^{41}$

Mu 'tezile, Hāriciler ve muhaddislerin ekseriyetine göre iman; hakk'a inanmak, onu dil ile ikrar etmek ve onunla amel etmek şeklindeki üç ilkeden ibarettir. ${ }^{42}$ Buradaki hakk kelimesinden kastedilen, dinin zarūrī esasları manasındaki bātılın zıddı olan hakk'tır. ${ }^{43}$

İmāmiyye Şî‘â'sının önemli âlimlerinden olan Şerīf el-Murtażā (ö. 436/1044) ${ }^{44}$ ise bu konuda kendilerinin (İmāmiyye), Mu'tezile'ye muhalefet ettiklerini; ancak Zeydiyye'nin bir kısmının Mu'tezile gibi düşündüğünü söylemiştir. Dolayısıyla İmāmiyye Şî'â'sına göre fasık (büyük günah işleyen kişi), mümin olarak kabul edilmektedir. ${ }^{45}$

Hz. Peygamber'in hadislerinde Allah'a şirk koşmak, haksız yere adam öldürmek, iffetli kadına zina iftirasında bulunmak, zina yapmak, ana babaya karşı asi olmak, sihir yapmak, faiz yemek, yetim malı yemek, gıbet etmek, savaştan kacmak, hırsızlık yapmak ve içki içmek gibi tutum ve davranışlar büyük günahlar arasında sayılmıştır. ${ }^{46}$

39 Bkz. Taftaẓanī, Sa düddīn Mes 'ūd b. Ömer b. 'Abdillāh, Şerḥu'l-Maḳāṣıd, thk. İbrāhīm Şemsüddīn (Beyrut: Daru'l-Kütübi'l- 'İlmiyye, 1432/2011), 3/417-422; Muḥammed b. 'Ali b. Muhammed b. Ebi'l- 'İz el-Hanefi, Şerḥu'l-'Akideti't-Ṭaḥāviyye, thk. Aḥmed Şākir (Suudi Arabistan: Vizāretü'ş-Şuūni'lİslāmiyye, 1998), 314-318; Ebū Manșūr el-Māturīdī, Kitabü't-Tevḥīd, nşr. Bekir Topaloğlu, Muhammed Aruci (Ankara: İsam Yay., 2005), 601-610; Şerafettin Gölcük, Süleyman Toprak, Kelam (Tarih-EkollerProblemler) (Konya: Tekin Kitabevi, 2001), 110.

${ }^{40}$ Bkz. Ebū Hanīfe, Nu 'mān b. Sābit, el-Kūfî, Flḳhu'l-Ekber, thk. Muḥammed b. 'Abdirrahmān el-Hamīs (İmārāt el- 'Arabiyye: Mektebetü’l-Furkān, 1999), 55; Bekir Topaloğlu-İlyas Çelebi, Kelām Terimleri Sözlüğü (İstanbul: İsam Yay., 2010), 154.

${ }^{41}$ Bkz. Taftazani, Şerhu'l-Makāsıd, 3/417-422; Ebu'l-'İz el-Hanefi, Şerhu'l-Akideti't-Tahāviyye, 314318; el-Māturīdī, Kitabü't-Tevhīd, 601-610; Gölcük-Toprak, Kelam, 110.

${ }^{42}$ Beyżāvī Nāṣıruddīn Ebū Sa īid 'Abdullah b. Ömer, Envāru't-Tenzīl, thk. Muhammed 'Abdurrahmān elMar'aşlī (Beyrut: Dāru İhyāi’t-Türāsi'l-‘Arabī, 1997), 1/37; Gölcük-Toprak, Kelam, 122.

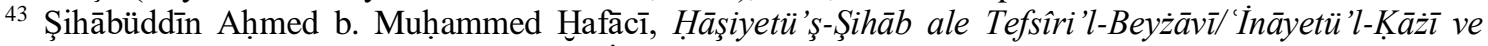
Kifāyetü'r-Rā̇īi, (Beyrut: Dāru'l-Kütübi'l- '̇llmiyye, 1997), 1/329-331.

44 Mustafa Öz, "Şerīf el-Murtażā", Türkiye Diyanet Vakfi İslam Ansiklopedisi (İstanbul: TDV Yay., 2010), 38/586-588.

45 Şerif el-Murtażā 'Alī b. el-Hüseynī el-Mūsevī, ez-Zeḩira fì 'İlmi'l-Kelām, thk. Seyyid Aḥmed elḤüseyn (Müessetü’n-Neşr el-İslāmī, 2010), 504.

46 Buhârî, Ebu Abdillâh Muhammed b. İsmail, Sahih-u Buhârî, thk. Muḥammed Züheyr b. Nâsır, Şerḥ: Mustafa Dîb el-Buğa (By.: Daru Tavki’n-Necât, 1422/2001), "Şehâdât", 10; "Vesâyâ", 24; "Diyyât", 2; "Edeb", 4, 49. 
Mezheplere göre imanın tanımı ve mahiyetini kısaca özetledikten sonra çalışmanın amacına uygun olarak Zemahşserî, Tabersî ve Râzî’nin tefsirlerinde bu konunun nasıl ele alındığını, söz konusu müfessirlerin bu konudaki görüşlerini, yorumlarını ve delillerini sirasıyla ele alabiliriz.

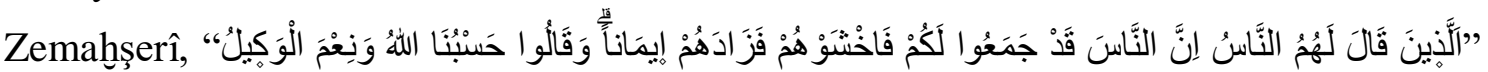
"Bazıları, 'İnsanlar sizin için (kuvvet) topladılar, artık o düşmanlardan korkun! Dediler. Bu da onların imānını artırdı ve "Allah bize yeter. O ne güzel vekildir, dediler." (Āli İmrān 3/173) ayetinin tefsirinde; Allah (c.c) yolunda düşmanla karşılaşmanın büyük bir ta'at olduğunu ve ta'atlerin de imandan sayıldığını ifade etmiştir. Ona göre iman; itikat/inanmak, ikrār ve amelden ibarettir. Zemahşşerî, delil olarak şu rivayeti zikretmiştir: “وعن عمر رضى اللَه عنه: أنه كان يأخذ بيد الرجل فيقول: قم بنا نزداد إيمانا" "Hz. Ömer'den nakledildiğine göre o, adamın elinden tutar ve 'Hadi kalk ibadet/zikir yapalım da imanımızı arttıralım.' derdi." $" 47$

Müfessir, Bakara Sūresi 3. ayetin ${ }^{48}$ tefsirinde de gerçek imanı, Hakk'a inanmak, bunu dil ikrar etmek ve ameliyle tasdik etmek şeklinde tarif etmiştir. ${ }^{49}$

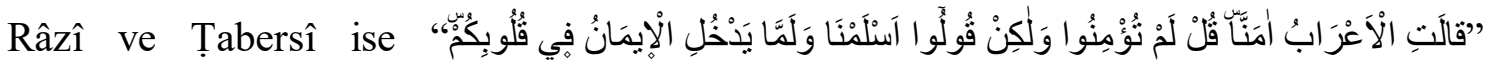
“Bedevīler 'İman ettik' dediler. De ki: 'İman etmediniz. Öyle ise 'iman ettik' demeyin. 'Fakat boyun eğdik' deyin. Henüz iman kalplerinize girmedi." (el-Hucūrāt 49/14) şeklindeki ayetin, imanın dil ile değil, ancak kalpte hasıl olduğuna delalet ettiğini söylemişlerdir. ${ }^{50}$

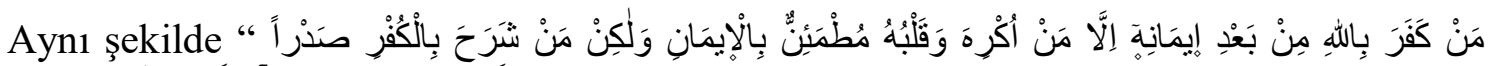
"Kalbi imanla dolu olduğu halde baskı altında kalanın durumu hariç olmak üzere, kim iman ettikten sonra Allah'1 inkâra saparsa ve ayrıca kim kalbini inkâra açarsa işte Allah'ın gazabı bunlaradır; bunlar için çok büyük bir azap vardır." (Nahl 16/106) ayeti de Râzî'ye göre imanın mahallinin kalp olduğuna delalet etmektedir. ${ }^{51}$

İtikādī mezhepler arasında imanın mahiyeti hakkında var olan bu farklılıklar, doğal olarak büyük günah işleyen Müslümanla ilgili olarak da farklı değerlendirmelere yol açmıştır. Örneğin böyle bir kimsenin inanç bakımından hangi konumda değerlendirilmesi gerektiği ve ahiretteki durumunun nasıl olacağı, âlimler arasında ihtilaflidir.

Mu'tezile'ye göre büyük günah işleyen kişi, fâsık olur. Onun yeri iki menzile arasında bir menziledir. Çünkü o, imāndan çıkmış ancak küfre girmemiştir. Böyle bir kişi tevbe

\footnotetext{
${ }^{47}$ Zemahşerî, el-Keşşāf, 1/442; 'Abdillāh b. Muhammed b. İbrâhîm b. Osmân b. Huvastī el-'Abes 1 Ebū Bekir b. Ebī Şeybe, Kitābu'l-Mușannef fi'l-Hadīsi ve'l- $\bar{A} s \underline{a} r$ (thk. Kemâl Yûsuf el-Hût (Riyâd: Mektebetu'r-Rüşd, 1988), 11/26; Alî b. Hüsâmiddîn b. 'Abdilmelik b. Kāàżhân el-Müttakḳī el-Hindî, Kenzü'l- 'Ummâl fí Süneni 'l-Aḳvâl ve'l-Ef'âl, thk. Bekrî Ḥayyânî, Șafvet Saḳâ (Beyrût: Muessesetü'rRisâle, Beşinci Baskı, 1981), 2/240. Ayrıca bk. İbrahim Bayram, "Bazı İman Konuları Bağlamında İbnü'l-Müneyyir'in Zemahşerî’ye Yönelik Eleştirileri”, Çukurova Üniversitesi İlahiyat Fakültesi Dergisi $18 / 1,225-226$.

48 "Onlar gayba iman ederler, namazı k1larlar, kendilerine verdiklerimizden hayra harcarlar." (el-Bakarâ 2/3)

${ }^{49}$ Zemahşerî, el-Keşşăf, $1 / 39$.

${ }^{50}$ Tabersî, Mecme 'u’l-Beyān 9/275; Râzî, Mefātīhu'l-Ġayb, 28/115-116.

${ }^{51}$ Râzî, Mefätīhu'l-Ġayb, 20/275.
} 
etmeden ölürse ebedī olarak cehennemde kalır. ${ }^{52}$ Hāricīler'e göre de imandan çıkıp kâfir olur. Onların nazarında imān ile küfür arasında, orta bir makam yoktur. ${ }^{53}$

Ehl-i Sünnet'e göre ise iman tasdikten ibaret olduğu için büyük günah işleyen kişi kâfir olmaz, mümin olarak kalır. Ancak işlenen günahı hafife almamak ve helāl saymamak şarttır. Şayet harāmı helāl sayarsa küfre düşmüş olur. Böyle bir kimse affedilmediği ve şefāate nāil olmadığı takdirde günahının cezasını çekmeden cennete giremez. ${ }^{54}$

Şia mezhebinin büyük çoğunluğu da Ehl-i Sünnet gibi düşünmekte ve fasık kişiyi mümin olarak görmektedir. ${ }^{55}$

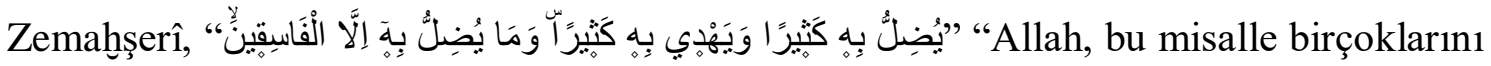
saptırır, birçoklarını da doğru yola iletir. Onunla ancak fasıkları saptırır." (el-Bakara 2/26) ayetinde geçen "fasık" kelimesini şöyle izah etmiştir: "Fâsık, kebīreyi (büyük günahı) işlemek suretiyle Allah'a itaat sınırının dışına çıkan kimsedir. O, iki menzile arasında bir yerdedir. Bu iki menzile, mümin ve kafir menzileleridir." Devamında, fasık kelimesinin bu tanımını ilk yapan kişinin Vāṣıl b. Atā olduğunu belirten Zemahşserî, ona yönelik 'Allah ondan ve taraftarlarından (Mu'tezile) razı olsun demiştir. Zemahşserî'ye göre fasık kişi nikahlanması, mirasçı olması, yıkanıp Müslüman mezarlığına defnedilmesi ve cenaze namazının kılınması yönüyle mümin hükmünde; zemmedilmesi, kendisine lanet edilmesi, inanç bakımından düşman kabul edilmesi ve şahitliğinin kabul edilmemesi yönüyle de kafir mesabesinde değerlendirilir. Zemahşserî, bu görüşüne delil olarak da şu ayetleri delil göstermektedir:

“"İmandan sonra fasılkk ne kötü bir isimdir!” (el-Hucurāt

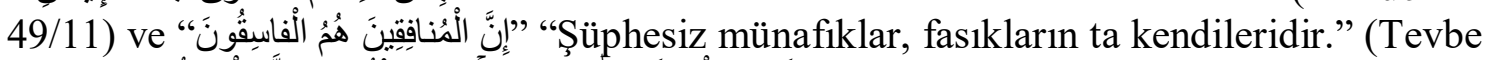
9/67) "Andolsun, biz sana apaç1k āyetler indirdik. Bunları ancak fasıklar inkâr eder.” (el-Bakara 2/99). ${ }^{56}$

Țaberŝ̂’ye göre yukarıda geçen (el-Bakara 2/26) ayetinde zikri geçen fasıklardan maksat, kafirlerdir. İnkarları sebebiyle Allah (c.c) onları saptırmıştır. Allah'ın, bu kimselerin kafir olduklarına dair hükmetmesi, onlara lanet etmesi ve onlardan berî olmas1; helak etmesi anlamına gelir. Neticede onları helak etmesi, onları saptırmas1 demektir. ${ }^{57}$

Aynı şekilde "Muhakkak ki sana apaçık ayetler indirdik. Onları ancak fasıklar inkâr eder." (el-Bakara 2/99) ayetinde geçen "fâsikûn" kelimesini "kafirler" olarak tefsir eden Țabersî, devamında fıskın, bir durumdan çıkıp başka bir duruma girmek olduğunu ve dolayısıyla ayette kendilerine işaret edilen Yahudilerin Hz. Muhammed'i yalanlamaları suretiyle, kendi dinlerinden (Hz. Mûsa'nın dini) çıkıp küfre girdiklerini ifade etmiştir. ${ }^{58}$

Ṭabersî"ye göre ayette kafirler kastedildiği halde "kâfirûn" değil de "fâsikûn" kelimesinin zikredilmesinin iki sebebi vardır:

\footnotetext{
${ }^{52}$ Bk. Beyżāvī, Envāru't-Tenzīl, 1/37; 'Abdullātif el-Harpūtī, Tenkīhu'l-Kelām fì 'Akāidi Ehl'i-İslām, çev. İbrahim Özdemir, Fikret Karaman (Ankara: TDV Yay., 2000), 216-217; Gölcük-Toprak, Kelam, 36; Topaloğlu-Çelebi, Kelām Terimleri Sözlüğü, 180.

53 Beyżāvī, Envāru't-Tenzīl, 1/37; Harpūtī, Tenḳ̄hu'l-Kelām, 216-217; Gölcük-Toprak, Kelam, 136; Topaloğlu-Çelebi, Kelām Terimleri Sözlü̆̆̈̈, 180.

${ }^{54}$ Bk. Beyżāvī, Envāru't-Tenzīl, 1/37; Harpūtī, Tenkīhu'l-Kelām, 216-217; Gölcük-Toprak, Kelam, 136; Topaloğlu-Çelebi, Kelām Terimleri Sözlüğ̈̈, 180.

55 Şerif el-Murtażā, ez-Zahīre, 504.

56 Zemahşerî, el-Keşşāf, 1/119.

57 Țabersî, Mecme 'u’l-Beyān, 1/90.

58 Țabersî, Mecme 'u'l-Beyān, 1/230.
} 
1. Bu kimselerin Allah'ın emrini çiğneyip en büyük günahları işlediklerine vurgu yapmak.

2. Küfürde bile çok aşırıya gittiklerine vurgu yapmak.

Zira ona göre küfrün kapsamı içerisinde olmayan fisk, en büyük günahların işlenmesi durumudur. Buna mukabil küfrün kapsamındaki fisk da küfrün en ileri boyutunu ifade eder. $^{59}$

Țabersî'nin son açıklamalarından anlaşıldığına göre o, her kafirin fasık olduğunu, ancak her fasıkın kafir olmadığını ifade etmektedir.

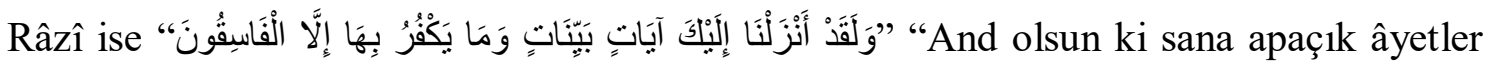
indirdik. Onları ancak fâsıklar inkâr eder." (el-Bakara 2/99) ayetinin tefsirinde fiskı, "Allah'a itaat sınırlarını aşmak" olarak tanımladıktan sonra genelde teaddînin (günahta aşırıya kaçmak) büyük olduğunda, fisk olarak isimlendirildiğini ifade etmiştir. Râzî̀ye göre her kafir fasıktır, ancak her fasık kafir değildir. Dolayısıyla fasık, kafir olmayanları da kapsar. ${ }^{60}$

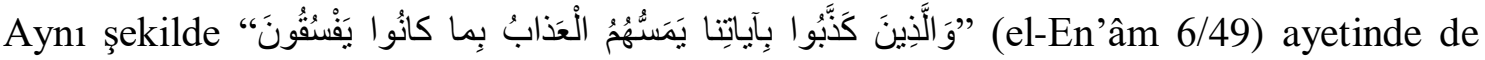
Râzî, Allah'ın birliğine, ahirete ve peygamberlere iman eden kimsenin fiskı ile bunları inkâr eden kafirlerin fiskının bir tutulmaması gerektiği üzerinde durmuştur. ${ }^{61}$

Ehl-i Sünnet'in önemli âlimlerinden biri olan Beydāvī, küfür ve iman arasındaki "fasıklı" menzilesinin üzerinde durmuş ve fasıklığ 1 mertebelere ayırarak meseleye tatmin edici bir izah getirmiştir. Ona göre fâsıkın üç mertebesi vardır:

1. Teğābī (التغابي) mertebesi: Cahillikten ve ahmaklıktan ötürü, hoşlanmadı̆̆ı halde bazen büyük günah işleyen kişinin durumu.

2. İnhimāk (الانهماك) mertebesi: Büyük günaha müptela olmuş ve aldırış etmeden bu günahı sürekli işleyen kişinin durumu.

3. Cuhūd (الجُحود) mertebesi: Büyük günahı doğru bir iş gibi görerek işleyen inkârc1 kişinin durumu.

Bir kişi "cuhūd" derecesine düşer ve bu yolda aşırı giderse, iman elbisesini çıkarmış, küfür elbisesini giymiş kabul edilir. Dolayısıyla ona kâfir denilir. Kişi "teğāẩ” ve "inhimāk" derecesinde devam ettiği müddetçe, iman ile muttasıf olduğu için o kimseye mümin denilir. Mu'tezile firkası ise "iman; tasdik, ikrar ve amelden ibarettir, küfür de hakkı yalanlayıp inkâr etmektir", ${ }^{2}$ görüşünde olduğu için "teğāẩ” ve "inhimāk derecesinde olan" fâsık kişiyi mümin ve kâfirin dışında, üçüncü bir kısma dāhil etmişlerdir. Onlara göre bu kişi iman ile küfür arasında bir yerdedir (el-menziletü beyne'l-menzileteyn). Çünkü her ikisiyle de ortak olduğu bazı noktalar vardır. ${ }^{63}$

\footnotetext{
59 Țabersî, Mecme 'u'l-Beyān, 1/230.

${ }^{60}$ Râzî, Mefātīhu'l-Giayb, 3/615.

${ }^{61}$ Râzî, Mefātīhu'l-Gayb, 12/537.

${ }^{62}$ Bk. Beyżāvī, Envāru't-Tenz̄̄l, 1/37, 64; Mehmet Bağış, "Envāru’t-Tenz̄̄l'de Kelām Uygulamaları ve Farklı İtikādī Görüşlerin Değerlendirilmesi”, Şırnak İlahiyat Fakültesi Dergisi 18/3 (2017), 49.

${ }^{63}$ Beyżāvī, Envāru't-Tenzīl, 1/64. Geniş bilgi için bk. Bağış, "Envāru’t-Tenzīl'de Kelām Uygulamaları", 47-48.
} 


\subsection{Zemaḩşerî, Ṭabersî ve Râzî’nin Tefsirlerinde İman-Amel İlişkisi Bağlamında Şefaat}

Şefaat, "çift”" manasındaki الَََََّفْ kökünden türemiştir. ${ }^{64}$ Lügatte çift yapmak, eş olmak, destek olmak, aracı olmak, istemek, dua etmek, başkası için istekte bulunmak ve ilave etmek gibi anlamlara gelmektedir. ${ }^{65}$

İslam inancında pek çok tartışmanın yaşandığı konulardan birisi de Şefaat meselesidir. $\mathrm{Bu}$ tartışmalar, şefaatin varlığından ziyade, kimler için söz konusu olduğuyla ilgilidir. ${ }^{66}$ Mu'tezile'den Kāż̀̄ Abdülcebbār'ın (öl. 415/1025) ifade ettiği üzere şefaatin varlığ konusunda ümmet ittifak etmiştir. Ona göre bunu inkâr edenler büyük bir hataya düşmüşlerdir. Ancak; şefaatin kimler için vaki olacağı konusunda görüş ayrılığ 1 bulunmaktadır. ${ }^{67}$

Yukarıda da işaret edildiği üzere esasında ehl-i sünnet ile Mu'tezile arasındaki ihtilaf, büyük günah işleyen kimseler için şefaatin vâkî olup olmayacağı hakkındadır. Çünkü müminlerin mükâfatının arttırılması için onlara şefaatin vâkî olacağı ve kâfirler için de şefaatin söz konusu olmadığı konusunda görüş birliği vardır. ${ }^{68}$ Dolayısıyla burada, âlimlerin ittifakıyla kabul edilen şefaatin varlığı üzerinde değil, daha çok mezhepler arasında büyük günah işleyen kimseler için şefaatin söz konusu olup olmayacağ üzerinde durulması icap eder.

Şefaat meselesi Ehl-i Sünnet, Mu'tezile ve Şî́â mezhep mensupları tarafindan genellikle şu ayetler etrafında ele alınmıştır:

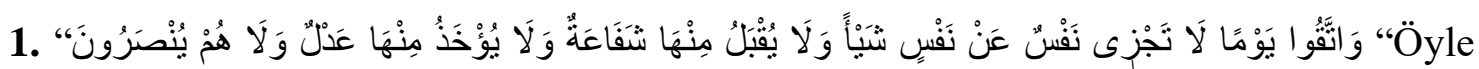
bir günden sakının ki o gün hiç kimse bir başkası adına bir şey ödeyemez. Hiçbir kimseden herhangi bir şefaat kabul olunmaz, fidye alınmaz ve onlara yardım edilmez." (el-Bakara 2/48)

Zemahşerî'ye göre ayetin sebeb-i nüzūlüyle ilgili haberlerde her ne kadar İsrailoğullarına yönelik indiği söylenmişse de bu ayetin hükmü geneldir. Dolayısıyla ayette dini bir emir ve yasağ 1 ihlal eden nefsin başka bir nefis tarafindan desteklenmesinin veya bu nefse şefaat edilmesinin yasaklandığı ifade edilmektedir. Ona göre bu ayet, büyük günah işleyenlere yönelik şefaatin kabul edilmeyeceğine dair delildir. ${ }^{69}$ Ayrıca o, Haşviyye ve Cebriye'nin büyük günahlar konusunda kendilerini Hz. Peygamberin şefaatiyle kandırdıklarını ifade etmiştir. ${ }^{70}$

\footnotetext{
64 Beyżāvī, Envāru't-Tenzīl, 1/78; Muhammed b. Mukrīm b. Manẓūr el-İfrīkịi el-Misrī, “شف", Lisânu’l'Arab (Beyrût: Dâru Sâdir, 1993), 8/183.

65 İbn Manzūr, Lisânu'l- 'Arab, 8/183-184; Rāg̣ıb el-Isfahānī, el-Müfredāt fì Garībi'l-Kur'ān, thk. Șafvān 'Adnān Dāvudī (Beyrut: Dâru'l-Ḳalem, 1991), 457; Muhammed b. 'Abdirrazzāḳ el-Ḥüseynī Zebīdī, Tācu'l- 'Arūs, (B.y.: Dāru'l-Hidāye, ts.), 21/282.

${ }^{66}$ Bk. Tabersî, Mecme 'u'l-Beyān, 1/140; Süleyman Narol, "Fahreddin Razi ve Kādī Abdülcebbār'ın Şefaat Konusundaki Ayetlere Yaklaşımı ve Değerlendirilmesi”, Kahramanmaraş Sütçü İmam Üniversitesi Illahiyat Fak. Dergisi, 26 (2015), 130.

${ }^{67}$ Ebu'l-Hasen 'Abdülcebbār b. Aḥmed b. 'Abdilcebbār b. Aḥmed b. el-Halīl b. 'Abdillāh el-Hemedānī, Fażlu'l-İ tizâl ve Tabakātu'l-Mu 'tezile, nşr. Fuâd Seyyid (Tûnus: Dâru'l-Kütübi't-Tûnusiyye, 1974), 207. Konuyla ilgili ayetlerin tefsiri için bk. Muhammet Yılmaz, "Hicri İlk Üç Asırda 'Şefaat' İle İlgili Ayetlerin Tefsiri”, Marife 14/1 (Bahar 2014), 114 vd.

${ }^{68}$ Bk. Râzî, Mefātīhu 'l-Ġayb, 3/495, 498.

${ }^{69}$ Zemahşerî, el-Keşşāf, 1/36-137.

${ }^{70}$ Zemahşerî, el-Keşşă $f, 1 / 349$.
} 
Ayetin siyâk ve sibâkına baktığımızda ise önceki ayette (el-Bakara 2/47) İsrailoğullarına verilen nimetlerden bahsedilmiştir. Sonraki ayette (el-Bakara 2/49) ise yine, İsrailoğullarının Firavun'un zulmünden kurtarılmaları hadisesi anlatılmıştır. Dolayısıyla İsrailoğullarından bahseden iki ayetin ortasındaki söz konusu ayette de muhataplar, müfessir Beydāvī’nin de işaret ettiğgi gibi küfür üzerinde bulunan Yahudilerdir. ${ }^{71}$

Ṭabersî ise ayette geçen "nefis" (نفس) kelimesinin nekre olduğunu, dolayısıyla her nefsi kapsadığını söylemiştir. Onun naklettiğine göre müfessirler, bu ayetin hükmünün Yahudilere has olduğunu söylemişlerdir. Çünkü Yahudiler, "Biz peygamberlerin çocuklarıyız ve babalarımız bize şefaat edecektir." diyorlardı. Allah (c.c) da ayette ifade edildiği üzere onların bu kuruntularını bertaraf etmiştir. Dolayısıyla ayet, umum (genellik) siğasında gelse bile husûs (Yahudilere has) hüküm ifade etmektedir. ${ }^{72}$

Țabersî, bu meselede "bize göre...” diyerek kendi mezhebi Şî‘â'nın görüșünü nakletmiştir. Onlara göre şefaat, kendilerinden azabın düşürülmesi veya kaldırılması için günahkâr müminlere has bir durumdur. Hz. Peygamberin, onun seçkin ashâbının, ehl-i beyt imamları ve bazı salih müminlerin şefaat edeceğini ve Allah'ın da (c.c) bunların şefaatiyle birçok günahkâr mümini azaptan kurtaracağını ifade eden Țabersî ${ }^{73}$, görüşünü ispatlamak maksadıyla şu iki rivayeti delil getirmiştir:

1. Hz. Peygamber şöyle buyurmuştur: "Ben şefaatimi ümmetimden büyük günah işleyen kimseler için sakladım.",74

2. Hz. Peygamber şöyle buyurmuştur: "Kıyamet günü bana şefaat yetkisi verilir ben de şefaat ederim, Ali'ye de verilir o da şefaat eder ve ehl-i beytime şefaat yetkisi verilir onlar da şefaat ederler. Müminlerden şefaat yetkisi en az olan kişi ise kardeşlerinden cehennemi hakketmiş kırk kişiye şefaat edecektir."75 Ṭabersî bu haberin, ashabından nakledilen merfü bir haber olduğunu söylemiştir. ${ }^{76}$

Râzî'nin Mefātīhu'l-Ġayb'da aktardığına göre ise Mu'tezile, bu ayete dayanarak büyük günah işleyenler için şefaatin vaki olmayacağını söylemiştir. Mu'tezile'ye göre büyük günah işleyenlere şefaat edileceğiyle ilgili gelen haberler, ahâd haberlerdir. Ahâd haberlerle elde edilen bilgi de zann ifade eder. Böylesine ilmî bir meselede zann ile hüküm vermek ise caiz değildir. ${ }^{77} \mathrm{Mu}$ 'tezile'den Kāżì Abdulcabbâr'a göre de bu haberin sıhhati sabit değildir. Sahih olsa bile bu haber āhād yolla aktarılmıştır. Haber-i vāhid de kesin bilgi ifade etmez. Dolayısıyla onunla ihticac etmek mümkün değildir."78

\footnotetext{
${ }^{71}$ Bk. Beyżāvī, Envāru't-Tenzīl, 1/78-79.

72 Tabersî, Mecme 'u'l-Beyān, 1/139-140.

73 Ṭabersî, Mecme 'u'l-Beyān, 1/140.

74 Ebū Dāvūd Süleymān b. Dāvud b. el-Cārūd et-Tayālisî el-Basrī, Müsned, thk. Muhammed b. 'Abdilmuhsin (Misır: Dāru'l-Ḥicr, 1999), 3/250; Aḥmed b. Hanbel, Müsned, thk. Şu'ayb el-Arnaût vd. (Beyrut: Müessesetu'r-Risāle, 1999), 20/439; Ebū Dāvūd Süleymān b. el-Eş'as es-Sicistānī, Sünenü Ebī Dāvūd, ('Amman: Beytu'l-Efkāri'd-Devliyye, 1999), Sünne 23, (4/236); Muhammed b. 'İsā Ebū 'İsā esSülemī, el-Cāmiu 's-Sahīh Sünenu't-Tirmizî, thk. Aḥmed Muḥammed Şākir vd. (Beyrût: Dāru İhyāì'tTurāsi'l- 'Arabiyy, 1975), Kiyame 11, (4/203); Tabersî, Mecme 'u'l-Beyān, 1/140.

75 Benzer ifadeler içeren rivayetler için bk. Aḥmed b. Ḥanbel, Müsned, 25/188, 38/192; Tayālisî, Müsned, 2/612; Tirmizî, Sünen, "Sifetü'l-Kiyame”, 12 (2438).

76 Ṭabersî, Mecme 'u'l-Beyān, 1/140.

77 Râzî, Mefātīḥu’l-Ġayb, 3/497-498.

${ }^{78}$ Ebu'l-Hasen 'Abdülcebbār b. Aḥmed b. 'Abdilcebbār b. Aḥmed b. el-Hुalīl b. 'Abdillāh el-Hemedānī, Şerhu'l-Ușūli'l-Hamse, Ta'lik: Aḥmed b. el-Hüseyin b. Ebī Hāşim, tsh. Semîr Muṣtafā Rabāb (Beyrut: Dāru İhyāi't-Turāsi'l-'Arabiyye, 2012), 464. Kāżì Abdulcabbâr'a göre āhād haberin bilgi değeri konusunda ayrıntılı bilgi için bk. Eraslan, Abdulvasıf, Mu'tezile’de Haber Teorisi (Kādî Abdülcebbâr
} 
Mu'tezile mezhebi bu görüşüne delil olarak, Hz. Peygamber'in kevser havuzu başında vb. durumlarda günāhkar kimselere şefaat etmeyeceğini bildiren bazı rivayetler ileri sürüp bu rivayetleri de kendi görüşü doğrultusunda tevil etmiştir. ${ }^{79}$

Razī, Mu'tezile'nin bu iddiasına cevaben; kıyametin bazı zaman ve mekanlarında Hz. Peygamber'in şefaat etmeyeceğini bildiren hadislerin mutlak anlamda olmadığını ve birçok ayette Allah'ın (c.c) izin verdiği kimselerin şefaat edeceğinin bildirildiğini söylemiştir. Dolayısıyla ona göre Hz. Peygamber'in kıyametin belli mekān veya zamanlarında günāhkar kimselere şefaat etmesi mümkündür. ${ }^{80}$

Râzî, söz konusu ayetin tefsirinde Mu'tezile'nin "şefaat, sadece mükafatı hak kazanmış müminler için geçerlidir; büyük günah işleyenler için söz konusu değildir" şeklindeki görüşünü naklettikten sonra "Arkadaşlarımı/mezhebimiz şöyle dedi:" (قَالَ أَصْحَابُنَا:' diyerek konu hakkında kendisinin de içinde bulunduğu ehl-i sünnet'in görüşünü aktarmıştır. Bu görüşe göre azabı hakketmiş birisinin ya cehenneme girmemesi ya da girmişse de cehennemden çıkarılıp cennete girdirilmesi suretiyle azabının düşmesinde şefaatin etkisi vardır. ${ }^{81}$ Râzî, büyük günah işleyen müslümanlar için şefaatın mümkün olduğunu şu şekilde delillendirmektedir: Kur'ân'da Hz. İsâ'nın "Eğer onlara azap edersen, şüphe yok ki onlar senin kullarındır. Eğer onları bağışlarsan, yine şüphe yok ki sen mutlak güç sahibisin, hüküm ve hikmet sahibisin." (el-Māide 5/118) şeklindeki hitabında, Hz. İsâ şefaatçı konumundadır. Râzî’ye göre kendilerine şefaat edilenler ise şunlar olabilir:

1. Kâfirler

2. İtaatkār müslümanlar

3. Küçük günah işleyen müslümanlar

4. Büyük günah işleyip tevbe eden müslümanlar

5. Büyük günah işleyip tevbe etmemiş müslümanlar.

Bunların (kendilerine şafaat edilenler) birinci grup (kafirler) olması uygun değildir. Çünkü ayetin ikinci kısmında "Eğer onları bağışlarsan, şüphe yok ki sen mutlak güç sahibisin, hüküm ve hikmet sahibisin." denilmektedir. İki, üç ve dördüncü grup olması da uygun değildir. Çünkü bu kimselerin azaplandırılması muhaliflere (Mu'tezile vb.) göre de caiz değildir. Bu durumda geriye sadece büyük günah işleyip tevbe etmemiş olanlar kalmaktadır. Hz. İsâ'nın risaletine göre bu gibi kimselere şefaat edilecekse, Hz. Muhammed'in risaletine göre de şefaat edilir. Aynı şekilde Hz. İbrahim'in Allah'a hitabını ihtiva eden şu ayet de bu minvalde değerlendirilebilir. "Artık kim bana uyarsa, o bendendir. Kim de bana karşı gelirse, şüphesiz sen çok bağışlayan, çok merhamet edensin." (el-İbrahim 14/36). ${ }^{82}$

Örneği) (Ankara: İlâhiyât Yayınları, 2020), 167. Kāżī Abdulcabbâr'ın şefaat konusundaki rivayetlerin Kur'ân ve akla aykırılığı yönündeki yaklaşımı için ayrıca bk. Eraslan, Abdulvasıf, "Mu'tezile’ye Göre Hadis Tenkid Kriterleri: Kādî Abdülcebbâr Örneği”, Hadis Tetkikleri Dergisi 17/2 (Aralık 2019), 129, 132.

${ }^{79}$ Râzî, Mefātīḥu'l-Ġayb, 3/497-498.

${ }^{80}$ Râzî, Mefātīhu'l-Gayb, 3/504.

${ }^{81}$ Râzî, Mefātīhu 'l-Ġayb, 3/495-496.

${ }^{82}$ Râzî, Mefātīhu'l-Ġayb, 3/498. 


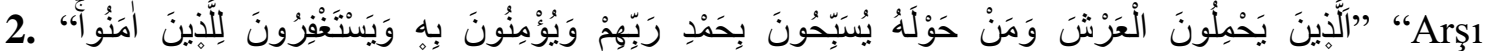
yüklenen melekler ile onun çevresindekler Rablerini hamd ile tesbih ederler, O'na iman ederler ve müminlerin bağışlanmasını dilerler." (el-Mü'min 40/7)

$\mathrm{Bu}$ ayette meleklerin önce Allah'1 tesbih ettikleri daha sonra Allah'a iman ettikleri zikredilmiştir. Halbuki Allah'ı tesbih etmek imanın kapsamı içerisindedir. Zemahşşerî'ye göre bunun sebebi, imanın şerefinin ve faziletinin ortaya çıkması ve insanların ona rağbet etmesinin sağlanması içindir. Amelin imandan bir cüz olduğunu iddia eden Zemahşerî, aynı gayeye matuf olarak imandan sonra salih amellerin zikredildiğini beyan etmiştir. ${ }^{83}$ Netice itibariyle ameli, imanın kapsamı içerisinde değerlendiren Zemahşerî'ye göre büyük günah işlemek suretiyle (salih) amel maddesini ihlal eden kimseler, ayette ifade edilen meleklerin mağfiretine erişemeyeceklerdir.

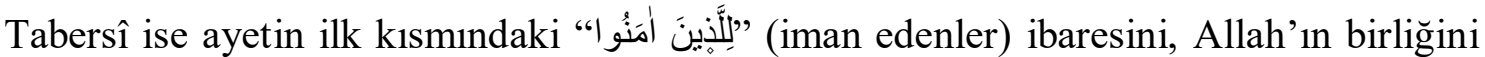
tasdik edip ulûhiyetini itiraf eden kimseler olarak tarif etmiştir. ${ }^{84}$ Tabersî'nin bu tarifine göre amel, imandan sayılmamaktadır. Dolayısıyla büyük günah işlemiş olsa da iman etmiş herkes ayette ifade edilen meleklerin istiğfarına mazhar olur.

Râzî’ye göre ise yukarıdaki ayet şefaatin bütün müminler için vaki olacağına delalet etmektedir. Ayette yüce Allah, meleklerin müminler için istiğfarda bulunacaklarını haber vermektedir. Büyük günah işleyen de sonuç itibariyle mümin olduğundan, bu

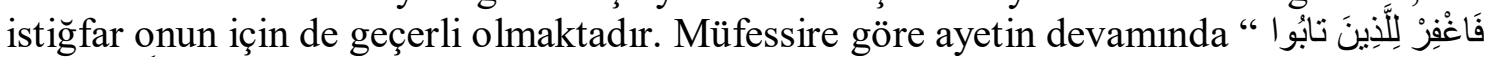
"Ey Rabbimiz! Tövbe eden ve senin yoluna uyanları bağışla.” gelmişse de bu kısım, ayetin öncesindeki âmm ${ }^{85}$ hükmün tahsis edilmesini gerektirmez. Çünkü fikıh usūlünde āmm lafızdan sonra onun bazı kısımları zikredilirse -ki bu kısımlar hâss ${ }^{86}$ olur- bu durumda āmm hükmün tahsis edilmesi gerekmez. ${ }^{87}$

Yukarıdaki ayetin ilk kısmında meleklerin iman edenler için bağışlanma dileyeceği

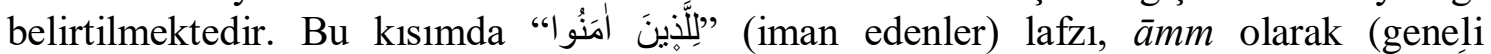

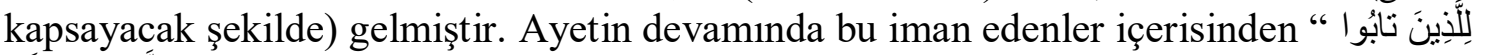
"وَانََّعُو اسَبِيَكَكَ (tövbe edip senin yoluna uyanlar” kısmı hāsstır. Râzî’ye göre ayetin ikinci kısmında her ne kadar tövbe edip Allah yoluna uyan müminler hāss olarak zikredilmişse de fikıh usūlünde işaret edildiğ ${ }^{88}$ gibi ayetin ilk kısmında gelen āmm hüküm devam eder. $\mathrm{Bu}$ hükme göre melekler Allah (c.c) katında, bütün müminler için istiğfarda bulunacaklardır.

Râzî’nin bu meselede ileri sürdüğü delillerden birisi de konu hakkında var olan şu rivayetlerdir:

\footnotetext{
${ }^{83}$ Zemahșerî, el-Keșşāff, 4/152.

${ }^{84}$ Tabersî, Mecme 'u'l-Beyān, 8/324.

${ }^{85}$ Konuluşu itibariyle delālet ettiği bütün fertleri sınırsız olarak aynı anda kapsayan lafza âmm denir. Bk. 'Abdulvehhāb Hallāf, 'İlmu Usūli'l-Fıkh (B.y.: Mektebetü'd-Da 'vā, ts.), 177-178.

86 Hāss: Tek bir manayı (bu mananın kendisinde gerçekleştiği fertleri) teker teker göstermek üzere konulmuş lafizdır. Muhtevasında çokluk manası bulunmakla birlikte çokluğun sınırlı olduğu lafizlar da hâsstır. Bk. Zekiyüddīn Şāban, İslām Hukuk İlminin Esasları, çev. İbrahim Kāfi Dönmez (Ankara: TDV Yay., 2018), 311; Mehmet Erdoğan, Fıkıh ve Hukuk Terimleri Sözlüğü (İstanbul: Ensar Neşriyat, 2016), 183.

${ }^{87}$ Râzî, Mefātīhu 'l-Ġayb, 3/501.

${ }^{88}$ Şaban, İslām Hukuk Ilminin Esasları, 353.
} 


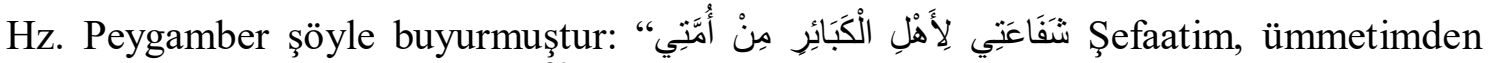
büyük günah işleyenler içindir." 89

Ebû Hüreyre'den nakledilen bir hadiste de Hz. Peygamber şöyle buyurmuştur: "Her peygamberin makbul bir duası vardır. Onlar da bu dualarını dünyada kullanmışlardır. Ben ise bu duamı kıyamet gününde ümmetime şefaat etmek için sakladım. İnşallah bu duam ümmetimden Allah'a şirk koşmadan ölmüş herkese ulaşacaktır." 90

Diğer bir hadis de özetle şöyledir: "Kıyamet gününde insanların çok büyük sıkıntıya düştüğü ve bütün peygamberlerin şefaat etmekten çekindiği bir anda Hz. Peygamber'in büyük günah işleyenler dahil bütün müminlere şefaat edeceği bildirilmektedir." 91

Mu'tezile'ye göre bu gibi rivayetler haber-i vâhid şeklinde nakledilmişlerdir. Halbuki böylesine önemli bir meselede bunların tevatür derecesine ulaşması gerekmektedir. Dolayısıyla zann ifade ettikleri için delil olarak kabul edilmezler. ${ }^{92}$

Râzî, burada Mu'tezile'ye şöyle cevap verildiğini söylemektedir: Bu gibi haberler senet itibariyle haber-i vâhid olsalar da sayı itibariyle çok fazla olup, mana olarak da birbirini desteklemektedirler. Bütün bu rivayetlerdeki ortak nokta ise büyük günah işleyenlerin şefaat sebebiyle affedilmesi hususudur. Dolayısıyla bu konudaki rivayetlerin çokluğu tevatür hükmünde değerlendirilebilir. ${ }^{93}$ Nitekim ehl-i sünnet âlimlerinin geneli bu konudaki rivayetleri manen mütevātir seviyesinde görmektedir. ${ }^{94}$

Râzî’nin aktardığına göre filozoflar şefaati şu şekilde tevil etmiştir: Vācibü'l-vücūd (Mevcudiyeti zorunlu varlık/Allah), bir lütfu/nimeti herhangi bir varlığa aktarmak istediğinde o varlık, söz konusu lütfu/nimeti almaya müsait olmayabilir. Dolayısıyla kendisine iletecek başka bir varlığa ihtiyaç duyar. Örneğin güneş 1şığı evin tavanına direk temas etmez. Ancak evin zemininde su dolu bir kap olursa, o suya temas eden 1 şık suyun aksettirmesi ile tavana yansır. İşte o su, güneş 1şığı ile tavan arasında bir aracı olur. Neticede peygamberlerin ruhları da Vācibü'l-vücūd ile sıradan insanların ruhları arasında bir aracidır. ${ }^{95}$

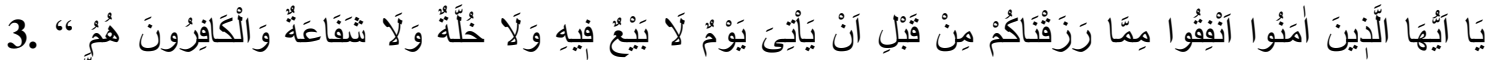
Ey iman edenler! Hiçbir alışverişin, hiçbir dostluğun ve hiçbir şefaatin olmadığ kıyamet günü gelmeden önce, size rızı olarak verdiklerimizden Allah yolunda harcayın. Kâfirler ise zalimlerin ta kendileridir" (el-Bakara 2/254).

Zemahşerî’ye göre yukarıdaki ayet kıyamet gününde cezaların düşürülmesi konusunda şefaatin bulunmadığını vurgulamaktadır. Ona göre şefaat, ancak müminlerin derecelerinin yükseltilmesi için yapılabilir. Zemahşserî "Kafirler, zalimlerin ta kendileridir." ifadesindeki "kafirler" kelimesini, "zekâtı vermeyenler" olarak tevil etmiştir. Ona göre Allah Teâlâ, zekâtı vermemenin büyük bir günah olduğunu ifade etmek için zekâttan kaçınanları küfürle tavsif etmiştir. ${ }^{96}$

\footnotetext{
89 Tayālisî, Müsned, 3/250; Aḥmed b. Hanbel, Müsned, 20/439; Ebū Dāvūd, Sünen, Sünne 23, (4/236); Tirmizî, Sünen, Kiyāme 11, (4/203).

${ }^{90}$ Râzî, Mefātīhu'l-Gayb, 3/502.

${ }^{91}$ Râzî, Mefātīhu'l-Ġayb, 3/502-503.

92 Râzî, Mefātīhu'l-Gayb, 3/503.

${ }^{93}$ Râzî, Mefātīhu 'l-Ğayb, 3/503.

94 Ayrıntılı bilgi için bk. Akif Akay, İslam Inancında Şefaat, (Konya: Necmettin Erbakan Üniversitesi, Sosyal Bilimler Enstitüsü, Doktora Tezi, 2012), 77.

${ }^{95}$ Râzî, Mefātīhu'l-G̈ayb, 3/504.

${ }^{96}$ Zemahş̧erî, Keş̧̧āf, 1/299.
} 
Tabersî'ye göre ise ayette asıl vurgulanmak istenen durum, kıyamet gününün çok dehşetli bir gün olduğu ve o günün zorluklarıdır. Müminlerin ve onların peygamberlerinin kıyamet gününde şefaat edeceklerini ifade eden Țabersî, buna delil olarak şu ayetleri ileri sürmüştür: “Onlar Allah'ın hoşnut olduğu kimseden başkasına

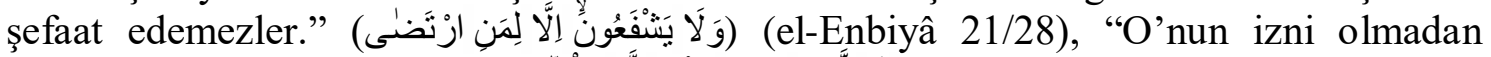

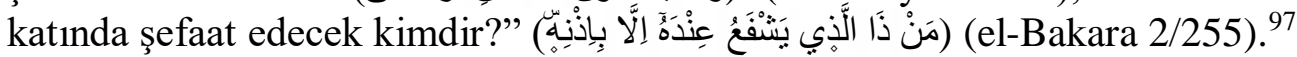

Râzî'nin Mefātīhü'l-Ğayb'ında Atā b. Yesār'ın şöyle dediği nakledilmiştir: 'Kâfirler zalimlerin ta kendileridir.' deyip, 'Zalimler kafirlerin ta kendileridir.' demeyen Allah'ıma şükürler olsun."98 Buradan hareketle Râzî, özetle ayetin şu şekilde tevil edildiğini nakletmiştir: Ayette; alışveriş, şefaat ve dostluk gibi vesilelerin kıyamet gününde kafirler için söz konusu olmayacağ1 ve müminlerin de onlara benzememeleri gerektiği anlatılmaktadır. Bunun yanı sıra ayetin başında "Hiçbir dostluğun ve hiçbir şefaatin olmadığı..." ifadesiyle hükmün mutlak olduğu vehmettirilmek istenmişse de devamında "Kâfirler, zalimlerin ta kendileridir." buyrulmak suretiyle kıyamet gününde alışveriş, dostluk ve şefaatin olmaması durumunun kafirlere has bir durum olduğu vurgulanmıştır. Dolayısıyla Râzî’ye göre ayet, fâsıklar (kafir olmayan zalimler) için şefaatın sabit olduğuna delalet eder. Râzî, "Kâfirler, zalimlerin ta kendileridir." cümlesinin ibtidaiye (yeni) bir cümle olup öncesiyle alakasının olmadığı, şeklindeki bir itirazı reddetmektedir. Böyle olması durumunda (hāşā) Allah'ın kelamında bir mantıksızlık olur. Çünkü kafir olmayıp zalim olan insanlar da vardır. Dolayısıyla ona göre ayetin başı ve sonuyla birlikte bütün halinde anlamlandırılması daha isabetlidir. ${ }^{99}$

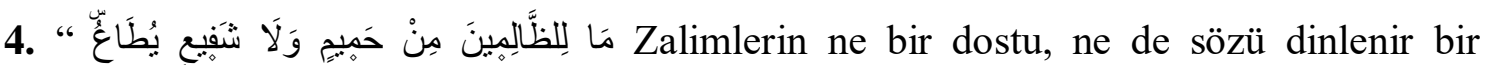
şefaatçisi olacaktır” (el-Mü'min 40/18)

Zemahşserî, bu ayetin tefsirinde şefaatin, sadece müminlerin derecelerinin yükseltilmesi şeklinde olacağını ve müminlerin dişındaki gruplar için söz konusu olmadığını söylemiştir. Müfessir, bu görüşünü şöyle temellendirmektedir: Şefaat yetkisi ancak Allah'ın veli kullarına verilir. Allah'ın veli kulları da O'nun sevmediği ve razı olmadığ 1 birini sevmez ve razı olmazlar. Dolayısıyla ona şefaat etmezler. Şefaatin sadece sevap ehli müminler için vâkî olacağına şu ayet de delalet etmektedir: "Allah, onları işlediklerinin en güzeliyle mükafatlandırır ve lütfundan onlara fazlasıyla verir."

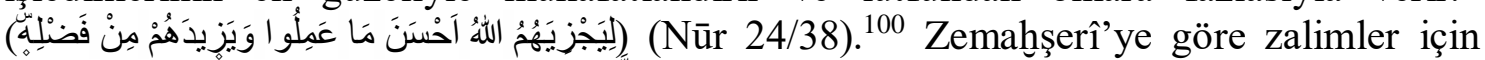

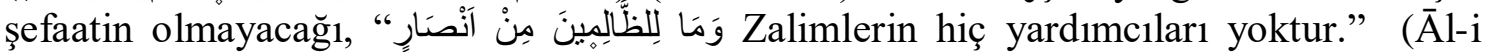
İmrān 3/192) ayetiyle sabittir. Zemahşerî, görüşünü desteklemek maksadıyla tabi 'înden Hasan-1 Basrî’nin şu sözünü de zikretmiştir: “Allah'a yemin olsun ki kesinlikle onların

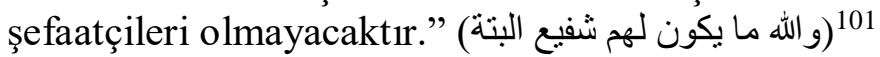

Țabersî ise ayette geçen zalimler kelimesi ile müşrik ve münafikların kastedildiğini ve dolayısıyla onlar için şefaatin söz konusu olmadığını ifade etmiştir. ${ }^{102}$

Râzî de bu ayetin tefsirinde "Zalimlerin itaat edilecek bir şefaatçileri yoktur." cümlesinin, "Hiçbir şefaatçileri yoktur" şeklinde anlaşılamayacağını söylemektedir. Örneğin birine, "Satılık kitabım yoktur." denildiğinde "Hiçbir kitabım yoktur." şeklinde bir mana anlaşılmaz. Dolayısıyla ayetin manası "Bu kimselerin Allah (c.c) tarafindan

\footnotetext{
97 Ṭabersî, Mecme 'u'l-Beyān, 2/128.

${ }^{98}$ Râzî, Mefätīhu'l-Ġayb, 6/531-532.

${ }^{99}$ Râzî, Mefātīhu'l-Gayb, 6/532.

100 Zemahşerî, el-Keşşāf, 4/158.

101 Zemahşşerî, el-Keşşāf, 4/158.

102 Tabersî, Mecme 'u'l-Beyān, 8/328.
} 
kendisine itaat edilecek şefaatçileri yoktur." şeklindedir. Nitekim hakikatte mertebe olarak kendisine itaat edilecek Allah'tan daha yüce bir varlık yoktur. ${ }^{103}$

Râzî burada bir nevi Allah'ın kudretine vurgu yapıldığını ifade etmiş olmaktadır. Râzî’ye göre de bu ayet kafirlere hastır. Çünkü onlar, putlarının Allah (c.c) katında ve O'nun iznine ihtiyaç olmaksızın kendilerine şefaatçi olacaklarını iddia ediyor ve putların şefaatinin herhalukarda kabul edileceğine inanıyorlardı. Bu da Allah'ın, onların putlarına itaat etmesi anlamına gelir. Bu sebeble Allah (c.c) onların bu yanlış itikatlarını reddetmiş ve "Zalimlerin itaat edilecek bir şefaatçileri yoktur." buyurmuştur. ${ }^{104}$

Lügavī açıdan bakıldığında ise (الظَّلَّمِينَ) kelimesi cemī (çoğul) sigasında olup başına harf-i tārif (ال) geldiği için önceki bir ma'hūd'a (cümlede zikri geçen bir nesneye) döner. O da ayetin öncesinde, Allah'ın ayetleriyle mücadele ettiklerinden bahsedilen kafirlerdir. ${ }^{105}$ Neticede Râzî, lügavi olarak da ayette muhatap kimselerin kafirler olduğunu ortaya koymuş olmaktadır.

Devamında o, ayeti mantık ilmi çerçevesinde tefsir ederek zalimlerden bir kısmını teşkil eden kafirlerin kıyamet gününde şefaatçıları ve dostları olmayacağını, ancak kafirlerin dışındaki diğer zalimler için şefaatın mümkün olduğunu ifade etmiştir. Buna göre Râzî, "Zalimlerin hiçbir dostu ve sözü dinlenir şefaatçıları yoktur." şeklindeki ayeti, cüz'i olumsuz bir önerme olarak kabul etmektedir. Olumsuz önermenin doğru kabul edilmesi için de olumsuzluğun bazı kısımlarda/fertlerde geçerli olması yeterlidir. Yani olumsuzluğun bütün kısımları/fertleri kapsamasına gerek yoktur. Netice itibariyle Râzî’ye göre ayetin manası şöyledir: Bazı zalimlerin hiçbir dostu ve sözü dinlenir bir şefaatçisi yoktur." Bu durumda şefaatçileri olmayanlar kafirlerdir. Ancak bazılarının da şefaatçileri vardır. Onlar da günāhkar müminlerdir. ${ }^{106}$

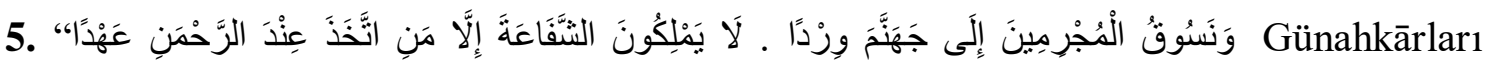
susuz olarak cehenneme sürdüğümüz gün, Rahmān'ın katında ahit alandan başkalarının şefāata güçleri yetmeyecektir.” (Meryem 19/86-87)

Zemahşerî̀ye göre Meryem Suresi 87. ayette geçen "şefaate malik olamayan kimseler" şefaatçiler değil, kendilerine şefaat edilecek olanlardır. Müfessir, devamında gelen "Rahmān'ın katından ahit alınması" meselesini de Mu'tezile mezhebinin düşüncesine uygun olarak, imanla birlikte amel etmek manasında yorumlamıştır. ${ }^{107}$ Netice itibariyle Zemahşerî, günahkarlar için şefaatin mümkün olmadığıını iddia etmektedir.

Ṭabersî ise ayette geçen "mücrim" kimselerin aslında kafirler olduğunu, dolayısıyla hem kendilerinin şefaatçı olamayacaklarını hem de başkalarının onlara şefaat edemeyeceğini söylemiştir. Ayette geçen "ahd" kelimesini ise iman, ikrār ve peygamberleri tasdik etmek şeklinde açıklamıştır. Ona göre Rahman'ın katından ahd/ahit alanlar, öncekilerden (kafirlerden) istisna edilmişlerdir. ${ }^{108}$ Dolayısıyla bu kimselere şefaat edilecektir.

Râzî’ye göre ise yukarıdaki ayetlerde büyük günah işleyen kimseler için şefaatin vaki olabileceğine delalet vardır. Râzî, Meryem/87. ayette "Rahmān'ın katından ahit alanlar" ifadesinde geçen ahdin, tevhit ve nübüvvetle alakalı olup, ahdi alan kimselerin de şefaat

\footnotetext{
${ }^{103}$ Râzî, Mefātīḥu'l-Ġayb, 27/504.

104 Râzî, Mefātīhu'l-Gayb, 27/504.

105 Râzî, Mefātīhu'l- $\dot{G} a y b, 27 / 504$.

106 Bk. Râzî, Mefātīḥu'l- $\dot{G} a y b, 3 / 503$.

107 Zemahşerî, el-Keşşāff, 3/43.

108 Ṭabersî, Mecme'u'l-Beyān, 6/345-346.
} 
edilmeyi hak eden müminler olduğunu ifade etmiştir. Râzî, görüşünü şu hadisle desteklemiştir: “Abdullāh b. Mes'ūd'tan gelen bir rivayette Hz. Peygamber: 'Sabah akşam Rabbinizin katından ahit almanız size zor gelir mi?' diye sormuş. Ashâb: 'Bu nasıl olur Yâ Rasulallâh?' dediler. Hz. Peygamber: 'Sizden birisi her sabah ve akşam şöyle demelidir: 'Gökleri ve yeri yaratan, görülen ve görülmeyen her şeyi bilen Allahım! Senden başka ilah olmadığına, hiçbir ortağının bulunmadığına ve $\mathrm{Hz}$. Muhammed'in senin kulun ve elçin olduğuna şehadet ettiğime dair ahdediyorum. Beni nefsimle başbaşa bırakırsan, nefsim beni şerre yaklaştırır, hayırdan uzaklaştırır. Sadece senin rahmetine güveniyorum. Kıyamet günü bana lütufta bulunacağına dair ahit ver. Çünkü sen va'dinden (sözünden) dönmezsin. Kişi böyle derse Allah (c.c) ona bir mühür vurur ve o, arşın altına götürülür. Kıyamet gününde bir münâdî (seslenen), 'Rahman'ın katında ahitleri bulunanlar nerededir? Onlar cennete gireceklerdir.' diye seslenir." 109 Râzî’ye göre hadiste geçen ahit, şehādet kelimesidir. Dolayısıyla büyük günah işlemiş olsalar da müminler, şehadet kelimesini getirmekle Rablerinden ahit almış olmaktadırlar. ${ }^{110}$

Görüldüğü üzere burada da Zemahş̧erî “ahd” kelimesini imanla birlikte amel, Ṭabersî ve Râzî ise sadece tasdik olarak mezheplerinin görüşleri doğrultusunda tefsir etmişlerdir.

\section{SONUÇ}

Sahabeden sonraki dönemlerde İslam devletinin sınırlarının genişlemesiyle birlikte Müslümanlarla gayri islâmî unsurlar, hayatın birçok alanında etkileşim içerisinde olmuştur. Bunun yanı sıra felsefe, mantık ve kelâm gibi ilimlerin de etkisiyle islâmî düşüncede meydana gelen değişme ve ilerlemeler doğal olarak Kur'ân yorumuna da etki etmiştir. Bunun neticesinde Kur'ân'1, itikâdî bir mezhebin ilkeleri çerçevesinde yorumlamaya çalışan mezhebî tefsirler veya firka tefsirleri diye nitelendirilebilecek tefsir çeşitleri ortaya çıkmıştır.

Mezhebî tefsirlerden sayılan Zemahşserî'nin el-Keşşāf, Tabersî'nin Mecme'u'l-Beyān ve Râzî'nin Mefātīhu'l-Ġayb isimli eserlerinde Kur'ân ayetleri, genellikle mezhebin temel ilkeleri çerçevesinde tefsir edilmiştir. İman-amel ilişkisi bağlamında büyük günah işleyen kimsenin dünya ve ahiretteki durumu ile şefaat meselesinin ele alındığ bu çalışma kapsamında Zemahş̧erî, Mu'tezile düşüncesine uygun olarak amelin imandan bir cüz olduğunu ve dolayısıyla büyük günah işleyerek (salih) ameli ihlal eden kimsenin mümin ve kâfir sayılmayıp, fâsık olarak nitelendirileceğini ifade etmiştir. Ayrıca o, fasık kimsenin ahirette şefaatten mahrum kalıp, iki menzile arasında bir menzilede olacağını bildirmiştir. Zemahşserî’ye göre bazı ayetler, taatlerin/amellerin imandan sayılıp onu arttırdığını beyan etmektedir (Āli İmrān 3/173). Aynı şekilde bazı ayetlerde de fasıklık, imanın kapsamı içerisinde sayılmamakta (el-Hucurāt 49/11, Tevbe 9/67, elBakara 2/99) ve fasık kişi için şefaat söz konusu edilmemektedir (el-Bakara 2/254, elMü'min 40/18, el-Meryem 19/86-87). Zemahşerî, düşüncesini ispat etme cihetinde ayetlerden, hadislerden ve yerine göre Arap dili verilerinden istifade etmiştir.

Ṭabersî ve Râzî ise imanın sadece kalp ile tasdik etmek olduğunu ve dolayısıyla büyük günah işleyen kimsenin hem mümin sayılacağını hem de kendisine şefaat edileceğini iddia etmişlerdir. Onlara göre bazı ayetler imanın dilde değil kalpte hasıl olduğuna ve mahallinin sadece kalp olduğuna açıkça işaret etmektedir (el-Hucūrāt 49/14, Nahl

\footnotetext{
109 Zemahşserî, Keşşaf, 3/44; Razi, Mefātīhu 'l-Ġayb, 21/565-566.

${ }^{110}$ Bk. Râzî, Mefātīhu'l-Gayb, 21/565-566, 3/499.
} 
16/106). Aynı şekilde iki müfessir, mutlak olarak müminlere şefaat edileceğini bildiren ayetlerin (el-Mü'min 40/7) yanı sıra büyük günah işleyenlere yönelik şefaatin var olduğunu ifade eden birçok hadis bulunduğunu aktarmışlardır. Hem Tabersî hem de Râzî görüşlerini ayetlerden, hadislerden ve lügavî yönden deliller getirmek suretiyle desteklemişlerdir. Buna ilave olarak Râzî, görüşlerini mantıkî ve felsefî tahlillerle birlikte, fikıh usulünden de yararlanarak delillendirirken; Tabersî, Şi'â'nın imamet anlayışına bağlı olarak Hz. Ali ve ehl-i beyt imamlarının şefaat edeceğini bildiren bazı hadisler ileri sürmüştür.

Zemahşerî̀nin ele aldığ1 Āli İmrān 3/173. ayette her ne kadar düşmana karşı durmanın büyük bir taat olup imanı arttırdığ 1 ifade edilmişse de bu taatin imandan bir parça olduğu zikredilmemektedir. Diğer yandan imanın sadece kalp ile tasdik olduğunu iddia eden Țabersî ve Râzî’nin delil olarak ileri sürdükleri ayetlerden el-Hucūrāt 49/14. ayette bedevilere yönelik "Öyle ise iman ettik demeyin, ancak boyun eğdik deyin. Çünkü iman henüz kalplerinize girmedi." denilmekte; Nahl 16/106. ayette ise "kalbi imanla dolu olduğu halde baskı altında kalan kimsenin Allah'ın (c.c) gazabına uğramayacağı" belirtilmektedir. Görüldüğü üzere bu iki ayette imanın mahalli kalptir.

Fasıklığın bazı ayetlerde imanın kapsamı içerisinde değerlendirilmediği iddiası karşısında da Țabersî ve Râzî fasıklığın küfürden daha genel bir durum olduğunu ve o ayetlerde zikri geçen fasıkların küfür üzerinde olan fasıklar olduğunu iddia etmişlerdir. Zira onlara göre her kafir fasıktır, ancak her fasık kafir değildir. Bu durumda bazı fasıklar mümindir ve tabii olarak bunlara şefaat edilebilir.

Görüldüğü üzere hem büyük günah işlemek suretiyle (salih) amel ilkesini ihlal eden kişinin inanç bakımından nasıl konumlandırılacağ 1 hem de bu kişiye şefaat edilip edilmeyeceği mevzusu, aslında mezheplerin "iman" için yaptıkları farklı tanımlamalarla alakalıdır.

Sonuç itibariyle büyük günah işleyen kimsenin dünya ve ahiretteki durumu ile şefaatin kimler için vâkî olacağ 1 problemlerinin cevabı, müfessirlerin bağlı olduğu itikâdî mezheplerin görüşleriyle orantılı bir şekilde tefsirlerine yansımıştır.

\section{KAYNAKÇA}

Akay, Akif. İslam Inancında Şefaat. Konya: Necmettin Erbakan Üniversitesi, Sosyal Bilimler Enstitüsü, Doktora Tezi, 2012.

Arpa, Enver. Zemahşerî’nin Tefsirdeki Yeri. Ankara: Fecr Yay., 2012.

Bağış, Mehmet. "Envāru’t-Tenzīl'de Kelām Uygulamaları ve Farklı İtikādī Görüşlerin Değerlendirilmesi”. Şırnak Illahiyat Fakültesi Dergisi 18/3 (2017), 41-59.

Bayram, İbrahim. 'Bazı İman Konuları Bağlamında İbnü'l-Müneyyir'in Zemahşerî’ye Yönelik Eleştirileri”. Çukurova Üniversitesi Illahiyat Fakültesi Dergisi 18/1, 221-255.

Bermekī, Ebû 'Abbās Şemsudīn Aḥmed b. Muḥammed b. İbrāhīm b. Ebī Bekr el-İrbilī. Vefāyātu'l- 'Ayān ve Enbāu Ebnāi'z-Zemān. thk. İhsān 'Abbas. Beyrut: Dāru Șādir, 7. Basim, 1994.

Beyżāvī, Nāṣıruddīn Ebû Sa '̄id 'Abdullah b. Ömer. Envāru't-Tenzīl. thk. Muhammed 'Abdurrahmān el-Mar'aşlī. Beyrut: Dāru İhyāì't-Türāsi'l-'Arab̄i, 1997.

Buhârî, Ebu Abdillâh Muhammed b. İsmail. Sahih-u Buhârî. thk. Muhammed Züheyr b. Nâsır. Şerḥ. Mustafa Dîb el-Buğa. By.: Daru Tavki'n-Necât, 1422/2001. 
Cerahoğlu, İsmail. Tefsir Tarihi. Ankara: Fecr Yay., 2014.

Ebû Dāvūd, Süleymān b. el-Eş'as es-Sicistānī. Sünenü Ebī Dāvūd. 'Amman: Beytu'lEfkāri'd-Devliyye, 1999.

Ebû Hanīfe, Nu'mān b. Sābit el-Kūfí. Fikhu'l-Ekber. thk. Muhammed b. 'Abdirrahmān el-Hुamīs. İmārāt el- 'Arabiyye: Mektebetü'l-Furḳān, 1999.

Ebu'l- 'İz, Muhammed b. 'Ali b. Muhammed el-Hanefì. Şerhu'l-'Aḳideti't-Ṭahāviyye. thk. Aḥmed Şākir. Suudi Arabistan: Vizāretü'ş-Şuūni'l-İslāmiyye, 1998.

el-Enșārī, 'Abdurraḥmān b. Muḥammed b. 'Ubeydullāh Kemāluddīn el-Enbārī.

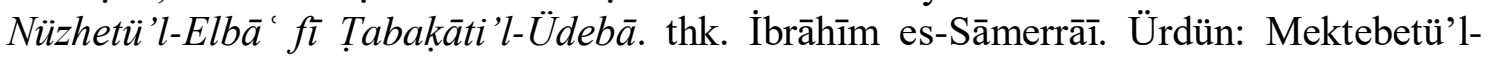
Menār, 1985.

el-Māturīdī, Ebû Manșūr. Kitabü't-Tevḥìd. nşr. Bekir Topaloğlu, Muhammed Aruci. Ankara: İsam Yay., 2005.

Eraslan, Abdulvasıf, Mu'tezile'de Haber Teorisi (Kādî Abdülcebbâr Örneği) Ankara: İlâhiyât Yayınları, 2020.

Eraslan, Abdulvasıf, "Mu'tezile’ye Göre Hadis Tenkid Kriterleri: Kādî Abdülcebbâr Örneği”, Hadis Tetkikleri Dergisi 17/2 (Aralık 2019), 119-138.

Erdoğan, Mehmet. Fıkıh ve Hukuk Terimleri Sözlüğü. İstanbul: Ensar Neşriyat, 2016.

Fahruddīn er-Râzî, Muhammed b. Ömer b. el-Hüseyn b. 'Ali el-Ḳureşī et-Teymī. Mefātīhu'l-Ġayb/et-Tefsîru'l-Kebīr. Beyrut: Dāru İhyāi't-Turāsi'l- 'Arabiyy, 1999.

Fığlalı, Ethem Rûhi. Gümüz İslam Mezhepleri. İzmir: İzmir İlahiyat Vakfi Yay., 2008.

Gölcük, Şerafettin-Toprak, Süleyman. Kelam (Tarih-Ekoller-Problemler). Konya: Tekin Kitabevi, 2001.

Gözeler, Esra. "Zemahsşerî Araştırmaları: Bir Literatür İncelemesi”. Kelam Araştırmaları Dergisi 14/1 (2016), 84-101.

Hafācī, Şihābüddīn Aḥmed b. Muhammed. Hāsşiyetü'ş-Şihāb ale Tefsîri'lBeyżāvīl'İnāyetü'l-Kāāì ve Kifāyetü'r-Rāìì. Beyrut: Dāru'l-Kütübi'l- 'İlmiyye, 1997.

Hallāf, 'Abdulvehhāb. 'İlmu Usūli’l-Fıḳh. B.y.: Mektebetü'd-Da'vā, 8. Basım, ts.

Harpūtī, 'Abdullātif. Tenkīhu'l-Kelām fì 'Akāidi Ehl'i-İslām. çev. İbrahim Özdemir, Fikret Karaman. Ankara: TDV Yay., 2000.

Hindî, Alî b. Hüsâmiddîn b. 'Abdilmelik b. Kāżīhân el-Müttaḳḳi. Kenzü'l- 'Ummâl fî Süneni'l-Akvâl ve'l-Ef'âl. thk. Bekrî Hayyânî, Șafvet Sakâa. Beyrût: Muessesetü'rRisâle, Beşinci Baskı, 1981.

Isfahānī, Rāg̀ib. el-Müfredāt fì Garībi'l-Kur'ân. thk. Șafvān 'Adnān Dāvudī. Beyrut: Dâru'l-Kalem, 1991.

İbn Ebī Şeybe, 'Abdillāh b. Muhammed b. İbrâhîm b. Osmân b. Huvastī el- 'Abes 1 Ebû Bekir. Kitābu'l-Mușannef fi'l-Hadissi ve'l- Āsār. thk. Kemâl Yûsuf el-Hût. Riyâd: Mektebetu'r-Rüşd, 1988.

İbn Hacer, Ebu'l-Fażl Aḥmed b 'Alī b. Muhammed b. Aḥmed el- Askelānī, Lisânu'lMīzān. thk. Dāiretu'l-Mu arrifi'n-Nizāmiyye Hindistan. Beyrut: Müessesetü'l-A 'lemi, 1971. 
İbn Hanbel, Aḥmed. Müsned. thk. Şu'ayb el-Arneût vd. Beyrut: Müessesetu'r-Risâle, 1999.

İbn Hatīb, Ebu'l-'Abbās Aḥmed b. Hasan. el-Vefayāt. thk. 'Ādil Nuveyhịid. Beyrūt: Dāru'l-Āfāḳi'l-Cedīde, 1983.

İbn Manẓūr, Muḥammed b. Mukrīm el-İfrīḳ̄ el-Misrī. “شفع", Lisânu'l- 'Arab. Beyrût: Dâru Sâdir, 1993.

İbn Şucā', Muḥammed b. 'Abdilg̀anī b. Ebī Bekr. İkmālü'l-İkmāl. thk. 'Abdulḳayyum, Mekke: Cāmia 'tu Ümmü'l-Ḳurā, 1989.

Kaya, Mehmet. "Keşşāf Tefsiri Hakkında Yapılmış Akademik Araştırmalar: Bir Literatür İncelemesi”. AUID 6/10 (Haziran 2018), 365-414.

Kāżī 'Abdülcebbār, Ebu'l-Ḥasen b. Aḥmed b. 'Abdilcebbār b. Aḥmed b. el-Hูalīl b. 'Abdillāh el-Hemedān 1. Fażlu'l-İ tizâl ve Trabakātu'l-Mu'tezile. nşr. Fuâd Seyyid. Tûnus: Dâru'l-Kütübi’t-Tûnusiyye, 1974.

Kāżì 'Abdülcebbār, Ebu'l-Ḥasen b. Aḥmed b. 'Abdilcebbār b. Aḥmed b. el-Ḩalīl b. 'Abdillāh el-Hemedānī. Şerḥu'l-Ușūli'l-Hamse. Ta'lik: Aḥmed b. el-Hüseyin b. Ebī Hāşim. tsh. Semîr Muștafā Rabāb. Beyrut: Dāru İhyāi't-Turāsi'l- 'Arabiyye, 2012.

Kıfțī, Cemālüddīn Ebu'l-Hasan 'Alī b. Yūsuf. Ahbāru'l- 'Ulemā bi Ahyāri'l-Hukemā. thk. İbrāhīm Şemsuddīn. Beyrut: Dāru'l-Kütübi'l-'İlmiyye, 2005.

Kutluboğa, Ebu'l-Fidā Zenūdudīn Ebu'l- 'Adl Kạsım. Tācu't-Terācim. thk. Muḥammed Hayr Ramażan Yūsuf. Dimeşk: Dāru'l-Kalem, 1992.

Narol, Süleyman. 'Fahreddin Razi ve Kādī Abdülcebbār'ın Şefaat Konusundaki Ayetlere Yaklaşımı ve Değerlendirilmesi”. Kahramanmaraş Sütçü İmam Üniversitesi Ilahiyat Fak. Dergisi, 26 (2015), 125-144.

Öz, Mustafa. “Ṭaberŝ̂” Türkiye Diyanet Vakfi İslam Ansiklopedisi. 39/324-325. İstanbul: TDV Yay., 2010.

Öz, Mustafa. "Şerīf el-Murtażā”. Türkiye Diyanet Vakf İslam Ansiklopedisi. 38/586588. İstanbul: TDV Yay., 2010.

Öztürk, Mustafa- Metoğlu, Mehmet Suat. “Zemahşer̂̂”. Türkiye Diyanet Vakfi İslam Ansiklopedisi. 44/235-238. İstanbul: TDV Yay., 2013.

Öztürk, Mustafa, “Tefsirde Farheddin er-Râzî”. İslām Düşüncesinin Dönüşüm Çağında Fahreddin er-Râzî. ed. Ömer Türker- Osman Demir. 279-346. İstanbul: İSAM Yay. Birinci Basım: Aralık 2013.

Saylan, Nesrişah, “Ṭabersî’nin Kırraatlerin Hüccetinde Kullandı̆̆ İncelenmesi”. Cumhuriyet İlahiyat Dergisi 23/2 (Aralık 2019), 977-991.

Sülemī, Muhammed b. 'İsâ Ebû 'İsâ. el-Cāmiu 's-Sahīh Sünenu't-Tirmizî. thk. Aḥmed Muḥammed Şākir vd. Beyrût: Dāru İhyyāi't-Turāsi' l- 'Arabiyy, 1975.

Şāban, Zekiyüddīn. İslām Hukuk İlminin Esasları. çev. İbrahim Kāfi Dönmez. Ankara: TDV Yay., 2018.

Şerif el-Murtażā, 'Alī b. el-Hüseynī el-Mūsevī. ez-Zeḩira fì 'İlmi'l-Kelām. thk. Seyyid Aḥmed el-Hüseyn. Müessetü’n-Neşr el-İslāmī, 2010.

Ṭabersî, Ebû Alī el-Fażl b. el-Ḥasen. Mecme 'u'l-Beyān li Tefsîri'l-Kur'ân. Beyrut: Dāru'l-'Ulūm, 2005. 
Taftazanī, Sa düddīn Mes'ūd b. Ömer b. 'Abdillāh. Şerḥu’l-Maḳ̄ṣıd. thk. İbrāhīm Şemsüddīn. Beyrut: Daru'l-Kütübi'l- 'İlmiyye, 2011.

Tayālisî, Ebû Dāvūd Süleymān b. Dāvud b. el-Cārūd el-Basrī. Müsned, thk. Muhammed b. 'Abdilmuhsin. Misır: Dāru'l-Hiicr, 1999).

Tefriş̄ī, Muṣtafā b. el-Ḥ̈seyn el-Hüseynī. Nakdu'r-Ricāl. thk. Müessesetü Āli'l-Beyti li İhyāì't-Türās. Kūm: Müessesetü Àli'l-Beyt li İhyāii’t-Türās, 1997.

Topaloğlu, Bekir- Çelebi, İlyas. Kelām Terimleri Sözlüğü. İstanbul: İsam Yay., 2010.

Türkgülü, Mustafa. "Günah Kavramı ve İman Problemi Haline Getirilen Büyük Günah/Kebire Hakkındaki Kelāmī Tartışmalar”. Diyanet İlmi Dergi 36/4 (Ekim-KasımAralık 2000), 63-88.

Yavuz, Yusuf Şevki, "Râzî”. Türkiye Diyanet İslam Ansiklopedisi. 12/89-95. İstanbul: TDV Yay., 1995.

Yılmaz, Muhammet. "Hicri İlk Üç Asırda 'Şefaat' ile İlgili Ayetlerin Tefsiri”. Marife 14/1 (Bahar 2014), 109-132.

Zebīdī, Muḥammed b. 'Abdirrazzāḳ el-Hüseynī. Tācu'l- 'Arūs. B.y.: Dāru'l-Hidāye, ts.

Zehebî, Muhammed Seyyid Hüseyin. et-Tefsîr ve'l-Müfessirūn. Kahire: Mektebetü Vehbe, ts.

Zehebî, Şemsuddīn Ebû 'Abdillāh Muhammed b. Aḥmed b. Osmān. el-Muġnī fi'ż$\dot{Z} u^{\prime} a$ 'fā. thk. Nureddīn 'Itr. B.y.: Y.y., ts.

Zehebî, Şemsuddīn Ebû 'Abdillāh Muḥammed b. Aḥmed b. Osmān. Mīzānu'l-İ'tidāl. thk. 'Alī Muhạammed el-Becāvī. Beryut: Dāru'l-Ma'rife, 1963.

Zemahşserî, Ebu'l-Kasım Mạ̣mūd b. 'Amr b. Aḥmed. el-Keşşāf 'an Haḳāiḳi Gavāmizì't-Tenzīl. Beyrut: Dāru'l-Kütübi'l- 'İlmiyye, 3. Basım, 1986. 